\title{
Prehistoric human responses to volcanic tephra fall events in the Ust-Kamchatsk region, Kamchatka Peninsula (Kamchatsky Krai, Russian Federation) during the middle to late Holocene (6000 to 500 cal BP)
}

\author{
I. Florin Pendea*, Hans Harmsen**, Dustin Keeler**, Ezra B. W. Zubrow ${ }^{a * *}$, Gregory \\ Korosec**, Erika Ruhl**, Irina Ponkratova***, Eva Hulse**
}

* Lakehead University, Sustainability Sciences Department, 500 University Avenue, Orillia, ON L3V0B9, Canada. ifpendea@lakeheadu.ca ** State University of New York at Buffalo, Department of Anthropology, 380 MFAC, Buffalo, NY 14261

***North International University, Portovaya str. 13 Magadan 685030, Russian Federation. ponkratova1@yandex.ru

${ }^{a}$ Corresponding author: ezubrow@gmail.com

\section{Abstract}

Prehistoric peoples in Kamchatka coped with recurrent volcanic tephra fall events during the middle to late Holocene. Recent data collected by the International Collaborative Circumpolar Archaeological Project (ICAAP) between 2009 and 2011 explores long-term relationships between drastic landscape change and concomitant human responses. A combination of new archaeological, paleoenvironmental and tephrochronological data demonstrate how the major Ksudach 1750 cal BP (KS1) eruption accelerated settlement relocation from the interior to the paleo-coastline.

\section{Introduction}

The Kamchatka Peninsula is one of the most volcanically active regions in the world with a dramatic geological history driven by large-scale tectonic processes taking place between the Eurasian, North American and Pacific plates (Ponomareva et al., 2007). On this dynamic 
landscape, pedogenic sediments have been interspersed with numerous volcanic ash layers (tephra) making the peninsula well suited for the precision dating of archaeological sites. The region has one of the best resolved Holocene tephra stratigraphies in the world due to the presence of well-preserved sedimentary archives such as peat and soil pyroclastic covers. Intensive tephrochronologic, volcanological and seismological research conducted over the past two decades has focused heavily on providing a high-resolution chronology of Late Quaternary volcanism and associated processes (Braitseva et al., 1992a, 1992b, 1997; Pevzner et al., 1998; Ponomareva et al., 2007, 2015; Kyle et al., 2011).

Between 2009 and 2011, the International Collaborative Circumpolar Archaeological Project (ICCAP) (NSF Award 0915131) conducted a series of archaeological and geological surveys to identify patterns in prehistoric human responses to rapid environmental change. Specifically, the project sought to document the relationship between prehistoric hunter-gatherer lifeways and recurrent landscape disturbance by tephra falls in the Ust-Kamchatsk region of eastern Kamchatka. The majority of tephra falls identified in the study area were produced by the still active volcanoes Shiveluch ( $\sim 65 \mathrm{~km}$ to the west) and Ksudach ( $\sim 00 \mathrm{~km}$ to the southwest). In addition to archaeological and geological survey, peat cores were collected in 2010 to reconstruct the paleoenvironmental record during the Late Quaternary. The longest core taken near Krutoberegovo village in the Ust-Kamchatsk region (Fig. 1) represents an uninterrupted environmental record spanning the last 15,000 years (Pendea et al., 2012, 2013, in preparation).

Volcanism and associated processes are experienced by human populations in various ways. These natural forcing events differ in their degree of predictability, probability and controllability, their speed of onset, their distribution (i.e. localized vs. diffused), and their adverse effects on people and the natural environment (Fritz, 1968). The impact of these events on human populations is mediated by the type of event (e.g., volcanic ejecta, seismic uplift, tsunamis), and responses vary significantly. This may include the degree and speed of abandonment of an affected area or reliance on larger regional support networks in times of crisis (Neall et al., 2008; Ort et al., 2008; Torrence et al., 2009). Volcanic events are not always catastrophic for human population living nearby. Sometimes a major volcanic eruption or 
tsunami may lead to a short-term abandonment and then re-occupation followed by social and political reorganization (Grattan, 2006; Begét et al., 2008; Hall and Mothes, 2008; Neall et al., 2008; Torrence et al., 2009).

The effects of large ash falls on terrestrial vegetation range from insignificant, at the edge of the ash plume, to complete obliteration of ecosystems in proximal areas (Antos and Zobel, 1985; Horrocks and Ogden, 1998a, 1998b). For instance, the Taupo eruption of 1718 cal BP in New Zealand drove widespread forest die-out ca. $160 \mathrm{~km}$ around the main eruption vent, and fires continued to affect the dying forest ecosystem for 150 years after the eruption (Horrocks and Ogden, 1998). More significantly, the Taupo eruption induced a major vegetational shift characterized by the expansion of a single tree species (Libocedrus bidwillii) to the detriment of others species over a period of several centuries. The effect of volcanic processes on fauna may be equally dramatic as is demonstrated by historical examples of mass mortality in the Aleutians (Black, 1981). Recovery periods extend into decades or centuries depending on the thickness of the tephra and area of distribution.

Reconstructions of the past social-environmental relationships, such as those offered by Adams (1978), Dilehay and Kolata (2004), Peeples, et al. (2006) and Hegmon et al., (2008) provide examples of causes and consequences of human choices within various socio-ecological systems (Folke, 2006). We hypothesize that similar to other hunter-gatherer cultures in close proximity to volcanically active regions (cf. McCartney and Veltre, 1999; Lowe et al., 2000; Galipaud, 2002; Sheets, 2007; Vanderhoek and Nelson, 2007; Begét, et al. 2008; Torrence, et al. 2009; Fitzhugh, 2012), middle to late Holocene populations in Kamchatka were able to endure in this highly dynamic environment due to their low population density, mobility and a willingness to opportunistically exploit a multitude of terrestrial, estuarine and marine ecosystems.

The geomorphologic and environmental diversity extant in the Kamchatka peninsula presents a unique case study in refining long-term, focused environmental archaeology in the context of adaptive human responses to catastrophic change. Human definitions of disaster emerge from pre-existing social relations and have the power to catalyze or trigger significant changes within socio-ecological systems (Watts, 1983). Understanding how prehistoric societies 
in Kamchatka reorganized their lives in the wake of major volcanic disasters allows us to gain insight into the larger patterns of human behavior that continue to persist in shaping modern perceptions of disaster and risk-mitigation. In this paper, we take the first steps toward linking human responses to catastrophic change during the middle to late Holocene in Kamchatka while simultaneously exploring what strategies prehistoric people employed to deal with environmental uncertainty.

\section{Regional Setting}

\subsection{Modern environment}

The Kamchatka Peninsula in the Russian Far East borders the Okhotsk Sea in the east, the Bering Sea in the west, and the North Pacific in the southeast. The climate of the peninsula is influenced by its position between the Siberian landmass and the North Pacific, as well as the presence of high mountain ranges that run parallel to the coasts for more than $1000 \mathrm{~km}$. In general terms, the climate is north boreal with strong maritime influences, but there are substantial climatic differences between regions. The central region is characterized by drier and warmer summers (sub-maritime to subcontinental) while the coastal regions are characterized by a maritime to sub-oceanic climate with persistent cool and humid conditions (Godelman and Pugayev, 1976; Krestov et al., 2008). Mean annual temperatures range from slightly above $0^{\circ} \mathrm{C}$ in the south to just below $0^{\circ} \mathrm{C}$ in the north (Bäumler and Zech, 2000; Zakharikhina, 2006). Mean annual precipitation ranges from $\sim 1000 \mathrm{~mm} /$ year in the southeast to $\sim 300 \mathrm{~mm} /$ year in the central mountains (Godelman and Pugayev, 1976; Bäumler and Zech, 2000; Zakharikhina, 2006). The average annual temperature in the study region (Ust-Kamchatsk weather station, $56.2^{\circ} \mathrm{N} 162.7 \mathrm{E}$ ) is $-0.33^{\circ} \mathrm{C}$ for the period between 1951 and 2010 . The average multi-annual precipitation for the same period is $718 \mathrm{~mm} /$ year.

The present day landscape is the product of millennia of climate change, sea level displacement, isostatic uplift, seismic activity, and significant volcanic events that include lahar processes and tephra falls. Geological evidence reveals stabilization between the coast and sea 
level around 5,000 cal BP (Bourgeois et al., 2006) when the Kamchatka Peninsula became connected to the mainland.

The present day landscape of the study region is characterized by a strong altitudinal gradient. Between sea level and $500 \mathrm{~m}$ above sea level (asl), the landscape is variegated and comprises three main ecosystems: (1) stone birch (Betula ermanii) woodlands, (2) tall grasslands dominated by grasses and sedges, and (3) fens characterized by sedges and mosses growing on wet soils. Above 500 meters stone birch woodlands give way to an oro-arctic shrub tundra dominated by shrub alder (Alnus fruticosa). Above $1000 \mathrm{~m}$ asl, the alder tundra disappears and is replaced by oro-arctic sedge tundra, unvegetated mineral soils and perennial snow.

Kamchatka's fauna is abundant but its diversity is rather low due to its peninsular geography and low connectivity to the mainland (Jones and Solomina, 2015). Forty mammal species, including nine marine mammals and 240 species of bird inhabit the Kamchatka peninsula including $50 \%$ of the world's entire population of Aleutian tern (Jones and Solomina, 2015). Eleven terrestrial mammals, 56 birds and six marine mammals are considered game animals today (Newell, 2004) and most likely would have been exploited by prehistoric populations in the region. Kamchatka's rivers host all 11 species of salmonid fish, including an estimated 20\% of the population of all species of anadromous Pacific salmon (chum, chinook, seema, pink, coho, and sockeye) (Newell, 2004; Jones and Solomina, 2015). The 1,852 rivers on the peninsula extend a total of $42,689 \mathrm{~km}$, and provide substantial spawning grounds. The spawning periods of the various species run from the beginning of June into November (Newell, 2004).

Osteological material dated to 1500 to $500-300{ }^{14} \mathrm{C}$ BP by Vereschagin and Nikolaev (1979) from the Zhupanovo site (Kronotski Bay, southeastern Kamchatka) represents a diverse array of both terrestrial mammals (polar fox and moose) and sea mammals (fur seal, sea otter, bearded seal and largha). The largest number of bird bones identified belonged to sea birds (Alcidae, Anatinae and Lari) with the exception of the short-tailed albatross (Diomedea albatrus) and Bewick's swan (Cygnus bewickii) (Savinetsky et al. 2004). 


\subsection{Culture History}

The majority of known sites in Kamchatka is restricted to the coast at the mouths of major rivers and date to no more than 3000 cal BP. These sites are characterized by numerous dwelling depressions that represent the remains of pit houses or yurts that date to the late Neolithic (Dikova, 1983; Ponomarenko, 1985; Ponomarenko, 2000) and later Itel'men culture (Ponomarenko, 1985). The material culture of these sites consists of maritime bone and stone artifacts that include flint blades, bone harpoons, and pottery.

Prehistoric cultural horizons in Kamchatka are classified according to the Eurasian material culture scheme of a Paleolithic/Mesolithic/Neolithic/Metal technology. Russian, North American, and European archaeologists all define Neolithic assemblages as including ceramic technology (Kuzmin and Orlova, 2000). As in other northern latitudes, such as northern Fennoscandia, the Neolithic period is not marked by agricultural economies. There is currently no historical ethnographic evidence (Krasheninnikov 1972 [1949]; Steller 1999) or archaeological evidence (Ponomarenko 2000) for the presence or production of ceramics among peoples of the Kamchatka River valley in prehistory. During the Neolithic, vessels were most likely fashioned out of wood into troughs and cups and baskets weaved from strips of birch bark. Meat and fish were cooked in such vessels by stone boiling (Krasheninnikov 1972 [1949]). Neolithic cultures continued to exist in Kamchatka until about AD 700 (Kuzmin, 2000), however stone, bone, and wood remained the raw materials of choice in many parts of Kamchatka until about 400 years ago. This traditional use of material culture by historic indigenous groups is commonly referred to as the "remnant Neolithic" (Dikov [1977] 2003; Hulse et al., 2011).

Most of the oldest settlements in Kamchatka are located in the Kamchatka River valley where numerous multi-component sites contain Paleolithic to Late Neolithic layers (Dikov, 1965; Goebel et al., 2003; Kuzmin et al., 2008). The Paleolithic hallmark in Kamchatka is the presence of "wedge shaped cores" similar to artifacts found from the same period in eastern Siberia and Alaska (Clark, 2001; Slobodin, 2001). The Early Neolithic of Kamchatka, 8000 to $6000 \mathrm{cal} \mathrm{BP}$, is characterized by lamellar blades and prismatic cores, burins, and projectile points

of obsidian. During the Middle Neolithic, $4500 \mathrm{cal} \mathrm{BP}$, the first pottery, and ground axes appear 
along with various other stone tools (e.g., knives and scrapers). Subsistence during this period was based on fishing, evidenced by the large amount of fish bones found at sites. By the onset of the Late Neolithic, ca. 3000 cal BP, two different economies formed. Fishing was the predominant form of subsistence in central and southern Kamchatka while reindeer hunting developed in the north (Dikov, 1965). The main cultural groups in the Kamchatka peninsula today include the Itel'men, the Koryaks, the Yukagir, the Chukchee, and the Evens. All of these groups continue to live on the Kamchatka peninsula and either hunt reindeer or rely on marine hunting and fishing.

The exploitation of salmon runs during the preceding Paleolithic and Early Neolithic periods is the earliest type of maritime adaptation in the region (Workman and McCartney, 1998). This maritime adaptation proceeded as a gradual movement of populations down rivers and streams from the interior to the coast of the peninsula (Ackerman, 1998; McCartney et al., 1998; Orekhov, 1998). By the Middle Neolithic period, maritime subsistence had intensified throughout the North Pacific, resulting in more sedentary coastal communities and a reliance on sea-mammal hunting (Lebedintsev 1998; Vasil'evskii 1998; Knecht and Davis, 2008).

The patterns observed in the Ust-Kamchatsk area conform to the known cultural sequences in this region. A reliance on fishing and waterfowl hunting was followed by a gradual adoption of a maritime economy that included sea mammal hunting over the course of the last 3000 to 4000 years. During the early stages, fishing practices developed in shallow waters and river mouths (Lebedintsev, 1998; Orkehov et al., 1998). Local populations would have moved seasonally between winter villages and summer camps (Orkehov et al., 1998). With the move toward a maritime and lacustrine subsistence strategy during the later Holocene (ca. 2000 to 1000 cal BP), populations were able to hunt year round and develop permanent settlements along lakes and paeloshorelines (Lebedintsev, 1998; Orkehov et al., 1998).

\section{Materials and Methods}

\subsection{Archaeological Surveys}

The objectives of the archaeological fieldwork performed by ICAAP were to (1) characterize 
archaeological sites in the Ust-Kamchatsk region through sampling, testing and excavation of sites, (2) obtain samples for radiocarbon dating, and (3) collect relative dates for sites based on localized tephra markers.

\subsubsection{Surface reconnaissance and soil sampling}

Surface reconnaissance along paleoshoreline terraces was performed to locate clusters of prehistoric dwelling depressions. Dwelling depressions range from small shallow round pits of the early periods to large deep square pits associated with later periods. When a new site was located, each depressions was given a GPS waypoint and characterized by size, shape and depth. After a grouping or cluster of depressions were identified, stratigraphic profiles were collected with an 3/4" Oakfield soil sampler in the center of depressions. Photographs were taken to document stratigraphic profiles. Using known tephra markers, these stratigraphic profiles assisted in assigning cultural sequences to sites in the field. All maps pertaining to the data collected were constructed using ArcGIS 10.2.

\subsubsection{Excavation and testing}

The most promising archaeological sites were further investigated using $50 \times 50 \mathrm{~cm}$ shovel tests, $1 \mathrm{x} 1 \mathrm{~m}$ test units and trench excavations. Test pits were excavated in $10 \mathrm{~cm}$ levels by shovel. Excavations were completed in several of dwelling depressions that demonstrated the longest occupation history. Excavation units were excavated with hand trowels at $5 \mathrm{~cm}$ levels. All soil and tephra removed from the unit was screened using $0.5 \mathrm{~cm}$ mesh screen. During excavation of the larger sites, all stratigraphic depths and in situ artifacts and features were point-plotted using a Trimble M3 Total Station. After excavation, wall profiles were drawn, detailed stratigraphic notes were taken and soil samples were collected.

\subsubsection{Ground penetrating radar}

In certain areas of the study, ground penetrating radar (GPR) data was collected using a threemeter antenna. Transect marks were placed at major changes in topography, but no more than 
two meters apart. GPR profiles were also collected along the edge of excavated units whenever possible. This allowed comparisons to be made between GPR and excavated profiles to improve interpretation.

\subsection{Radiocarbon dating}

Radiocarbon measurements were obtained on charcoal and plant macrofossils (Table 1). Macrofossils were identified to the lowest taxonomic level possible. AMS radiocarbon analysis was conducted at the National Ocean Sciences Accelerator Mass Spectrometry (NOSAMS) Laboratory in Woods Hole, Massachusetts. Quoted errors represent one relative standard deviation statistics (68\% probability) and counting errors are based on the combined measurements of the sample, background, and modern reference standards. Radiocarbon ages were corrected for isotopic fractionation and were calibrated using the IntCal13 curve (Reimer et al., 2013) employed in CALIB 7.1 (Stuiver et al., 2005). Calibrated ranges are reported as two standard deviations.

\subsection{Tephrochronology}

\subsubsection{In-field identification}

Our approach was to re-examine undisturbed tephra sequences in different parts of the study area and obtain new sequences in close proximity to archaeological excavations. The existing tephra database derived from stratigraphic sections in the study region (Braitseva et al., 1997; Pevzner et al., 1998; Ponomareva et al., 2007; Kyle et al., 2011) makes it possible to directly correlate individual tephra layers between sites. In some archaeological sites (particularly those with house pits), tephra layers were often disturbed. In these cases, direct tephra tracing was confirmed by tephra identifications with electron microprobe analyses of volcanic glass (Ponomareva et al., 2012, 2013, in preparation). Detailed investigation of minor tephra continues to be refined for the whole of the Kamchatka peninsula.

\subsubsection{Electron microprobe analysis}


Ponomareva et al. (2012, 2013, and in preparation) conducted $~ 1500$ analyses of individual glass shards from 70 tephra samples. All samples were washed in distilled water, dried, and lapilli crushed. Each sample was examined under the microscope and representative unaltered glass shards were selected for electron microprobe analysis. Volcanic glass was analyzed using a JEOL JXA 8200 electron microprobe equipped with five wavelength dispersive spectrometers. Three of the spectrometers used during the microprobe analysis at GEOMAR (Kiel) were high sensitivity at (two PETH and one TAPH) and developed according to the protocol developed by Maxim Portnyagin (GEOMAR) (see Ponomareva et al., 2013, 2015). The results will be presented and discussed in detail in a separate publication (Ponomareva et al., in preparation).

\subsection{Paleoecological analysis}

A comprehensive paleoenvironmental reconstruction based on palynomorph (pollen, testate amoebae, and fungal spores) and charcoal was conducted using materials from a $7 \mathrm{~m}$ long peat core spanning the last 15,000 years. The full results are published in separate papers (Pendea et al., 2012, 2013, in preparation). This core was extracted from a small fen basin nested in a former kettle depression near the village of Krutoberegovo (Fig. 2). For the purpose of this study we analyzed the charcoal and palynomorph signal at an increased resolution for two major volcanic eruptions $\left(\mathrm{SH}_{1964}\right.$ and $\mathrm{KS}_{1}$ in Table 2) in order to illustrate the effects of tephra fallout on the regional ecosystems.

One or half a centimeter thick subsamples were cut from the core every ten or five $\mathrm{cm}$, with thinner sections cut below and above tephra layers. Palynomorph preparation followed standard procedures for glycerine samples (Moore et al., 1991). Treated samples were washed over a $125-\mu \mathrm{m}$ sieve and the material retained on a $6-\mu \mathrm{m}$ sieve was used for analysis. A tablet containing a known concentration of exotic Lycopodium spores was added to each sample to allow calculation of pollen concentrations (Stockmarr, 1977). Palynomorphs were identified using published keys (Faegri et al., 1989; Moore et al., 1991; Kapp, 2000). For Betulaceae and Asteraceae we followed Blackmore et al. (2003) and Punt and Hoen (2009).

Greater than 400 pollen grains were counted in all samples excluding aquatic pollen and 
spores. Counts ranged from 402 to 3024. For samples with high number of Cyperaceae pollen, we counted at least 150 Lycopodium marker spores. Microscopic charcoal particles longer than $10 \mu \mathrm{m}$ (or area $>75 \mu \mathrm{m}^{2}$ ) were counted on pollen slides following Tinner and $\mathrm{Hu}$ (2003) and Finsinger and Tinner (2005). Pollen diagrams were generated using the Psimpoll 4.26 program (Bennett, 2007).

\section{Results}

\subsection{Radiocarbon dates}

Twelve radiocarbon samples were collected from two sites (Kultuk and Izvilisty) in 2009 and eight samples collected from other three sites (Stolbovaia, Summer Camp Lake and Kultuk) in 2010. Samples collected in 2011 are pending. Radiocarbon dates are presented in Table 1. Both charcoal and macrofossil samples (i.e., seeds, leaf epidermi, organic sediments) were obtained from in situ hearth features and wall profiles. Proximate depths were recorded for each sample to maintain stratigraphic integrity and for comparison with established tehprochronologies for the region.

Two sites, one at Stolbovaia and Kultuk were dated to approximately 6000 cal BP. The majority of the sites found in this region dated from $2500 \mathrm{cal} \mathrm{BP}$ to $500 \mathrm{cal} \mathrm{BP}$ based on ${ }^{14} \mathrm{C}$ and tephrochronological records. Many sites contained multiple occupations that spanned a 4000 year period. The oldest sites, dating to ca. 6100-6300 cal BP, were characterized by ephemeral occupations and found while excavating pit houses from later Neolithic periods. The oldest occupations found during the project occurred below the Shiveluch 4700 cal yr event $\left(\mathrm{SH}_{\mathrm{dv}}\right)$ tephra. At many sites, tephra layers were disturbed by younger occupation surfaces and it was necessary to excavate in order to identify the relative relationship with the tephra.

\subsection{Regional tephra markers}

The study area has experienced numerous heavy tephra falls during the Holocene and a tephrochronological summary for the study region is presented in Table 2. Tephra layers in the study area are described in detail by Bourgeois et al. (2006) and Pevzner et al. (1998). Bourgeois 
et al. (2006, Fig. 4) present a meridional tephra profile across the study area from Stolbovaia Bay in the north to Cherny Yar near the Kamchatka River in the south (Fig. 2).

Cherny Yar on the left bank of the Kamchatka River contains 34 individual tephra layers deposited during the last ca. 6800 cal years (Pevzner et al., 1998). Average frequency rate of heavy tephra fall events during the last 6800 years was estimated at one event per 191 years (Pevzner et al., 1998). However, heavy tephra fall frequency rate was variable in time with the highest rates occurring between ca. 2100 and 1400 cal ka BP (one event per 60 y) and 4700 and $4000 \mathrm{cal}$ BP (one event per $\sim 90 \mathrm{y}$ ). These frequency estimates are based on stratigraphic records of visible tephra layers. Actual tephra fall recurrence was probably much higher if we accept historical data as an analog for Holocene tephra fall activity. For example, since the last major eruption of Shiveluch in 1964, only one visible tephra layer was deposited in the area $\left(\mathrm{SH}_{2010}\right)$ (Ovsyannikov and Manevich, 2010). The actual number of reported tephra falls was far higher and included notable ash falls from Bezymianny (e.g., 1993 and 1995), Kliuchevskoi (e.g., 1990 and 1994), and Shiveluch (e.g., 1990 and 1993) eruptions (Pevzner et al., 1998). According to the stratigraphic evidence, the longest periods with relative volcanic quiescence are found between 3400-2700 and 2600-2100 cal BP (Pevzner et al., 1998). Detailed tephra stratigraphies for the area are also presented in several paleoseismological studies (Pinegina et al., 2012, 2013, 2014; Kozhurin et al., 2014).

The unique stratigraphic order and color characteristics of various tephra packages make field identification of tephra a rather straightforward process. Two of the most significant regional tephra markers for the area, namely $\mathrm{KS}_{1}$ and $\mathrm{AV}_{4}$, generated by Ksudach and Avachinsky volcanoes, and have been mapped by several authors (Braitseva et al., 1997; Pevzner et al., 1998; Kyle et al., 2011). Of the two, the $\mathrm{KS}_{1}$ tephra (ca. 1750 cal BP) is most widely dispersed, with uniform thickness of $5-8 \mathrm{~cm}$, making it one of the most valuable tephrochronological markers in the study region (e.g., Bourgeois et al., 2006; Pinegina et al., 2012, 2013, 2014). $\mathrm{KS}_{1}$ tephra is easily identifiable in the field due to its color and grain size characteristics (pale, fine to very fine ash with light-gray top) (Braitseva et al., 1996). The $\mathrm{KS}_{1}$ 
tephra was produced by the most recent caldera-forming eruption of Ksudach volcano (Southern Kamchatka), located $\sim 600 \mathrm{~km}$ southwest of the study area (Fig. 3).

Twenty eight tephra layers in the Cherny Yar outcrop are attributed to Shiveluch volcano, located $\sim 80 \mathrm{~km}$ west of the study area (Pevzner et al., 1998). Most of the Shiveluch tephra are fine to coarse grained, light or mixed colored (i.e., "salt-and-pepper"), with bulk andesitic and glass rhyolitic compositions (Kyle et al., 2011; Ponomareva et al., 2015). One of the most

prominent Shiveluch tephra in the area is a dark-gray cinder of unique high-K high-Mg composition (Volynets et al., 1997). Among the andesitic tephra in the region, $\mathrm{SH}_{1450}(\sim 1350 \mathrm{cal}$ $\mathrm{BP})$ and $\mathrm{SH}_{\mathrm{dv}}(4700 \mathrm{cal} \mathrm{BP})$ are the most prominent and easily identified in the field.

\subsection{Archaeological data}

From 2009 to 2011, the ICCAP project conducted 14 surveys and identified 60 sites in the UstKamchatsk region. Surveys were conducted on foot and by vezdekhood covering transects that collectively spanned over 160 kilometers. Figure 2 illustrates the general survey locations of the project in the Ust-Kamchatsk region. Table 3 lists survey locations and the number of corresponding number of prehistoric sites identified between 2009 and 2011. Targeted testing and excavations were performed at 30 sites to characterize local geomorphology and the archaeological record. Many of the sites contained multiple occupations that spanned over 4000 years.

The oldest sites that spanned from 6300 to 3100 cal BP were slight depressions and barely recognizable on the landscape. These older sites are representative of the Early Neolithic tradition in Kamchatka. Sites that ranged from 3000 to 1400 cal BP were characteristic of a Middle Neolithic phase and were differentiated between two general types. The first type tended to be small clusters of a few round shallow depressions. These small sites appear to be the result of relatively short-term occupations based on the presence of one hearth layer and little or no lithic material. Several of these sites contained burnt faunal material from small birds and mammals. The second type comprised more densely clustered concentrations of round depressions. These depressions were often one or more meters deep and suggest more sedentary 
long-term occupations that may have spanned generations. These occupations often contained a large amount of both lithic and faunal material.

The most recent sites date to ca. 1400 to $500 \mathrm{cal}$ BP. These sites were highly varied in character and comprised clusters ranging from two to three depressions to 20 or more depressions. These dwelling depressions were immediately identifiable by their great depth (often between 2 and 3 meters) and square shape. These sites represent a Late and/or remnant Neolithic phase.

Elevation was a key determinant in identifying depression clusters along the paleoshoreline. Older sites were frequently found at higher elevations. This reason for these high elevation sites is the result of isostatic uplift and sea line displacement during the middle to late Holocene. At least one major shoreline shift occurred from seismic uplift caused by a major movement of the Ust-Kamchatsky fault ca. 4700 cal BP (Pinegina et al., 2012). Before this uplift there was a lagoon environment in the area to the north of Lake Nerpich'ye. In areas to the south, the confluence of various estuaries created a number of small islands near the present day shoreline. Theses lagoons, river confluences, and small islands would have made for a rich and diversified mosaic of ecological niches.

In 2009, survey and excavations were conducted at Izvilisty and along contours of the paleoshoreline terraces at Lake Nerpich'ye at Kultuk. Team members tested the efficacy of performing fieldwork and linking the interaction between humans and the environment between 6000 and 4000 years ago. Preliminary information was gathered on the variability of the prehistoric sites, the volcanic landscape, and the use of tephra as a dating technique.

Transect field survey, shovel pit testing, ground penetrating radar and excavations were piloted in the Kultuk and Izvilisty locales. Initial observations suggested that: (1) prehistoric occupation in the region was neither rare nor ephemeral over time; (2) structural remains from prehistoric peoples were archaeologically visible; (3) multiple occupations of a singular location were frequent; and (4) extant material culture from occupations included a diverse array of features, stone tools and some faunal remains. A detailed description of the results of the 2009 is 
provided in Hulse et al. (2011). Summaries for the work performed in 2010 and 2011 are provided below.

\subsubsection{Kultuk}

In 2011, surveys at Kultuk were expanded based on knowledge from previous years and six large sites were identified along the paleoshoreline of Lake Kultuchnoye. Site 1 consisted of 13 depressions on a high terrace near Kultuk point. The depressions closer to the lake were relatively recent as evidenced by their depth and large square shape. They contained Late Neolithic and remnant Neolithic occupation layers. Depressions found further from the lake were smaller and shallow. Soil samples from these depressions contained occupation surfaces that fell below the $\mathrm{KS}_{1}$ tephra layer.

Site 2 consisted of 12 depressions in and around a half bowl shaped feature on a high terrace adjacent to Lake Kultuchnoye. Depressions found at the bottom of the bowl are large and deep and appear to represent long continuous occupations that begin below the $\mathrm{KS}_{1}$ tephra layer and extend to as recent as 500 years ago. The depressions on the edge of the bowl are small and shallow and contain deep occupation layers above and below the $\mathrm{SH}_{\mathrm{dv}}$ tephra.

Site 3 comprised a cluster of 11 depressions on a narrow ridge overlooking Lake Kultuchnoye. Depressions were characterized as a combination of Late Neolithic occupations and small shallow depressions with occupation layers found below the $\mathrm{KS}_{1}$ tephra.

Site 4 consists of 19 depressions arranged in rows on a high ridge overlooking the lake. All of the depressions at the site are round and shallow and range in diameter from $5 \times 5$ to $8 \times 8$ meters. Many small depressions were located adjacent to larger depressions. The occupation layers in this site are mainly found below the $\mathrm{KS}_{1}$ tephra. A number of GPR transects and $50 \times 50 \mathrm{~cm}$ tests were performed at the site. They revealed buried features outside of the depression with occupation surfaces above and possibly below the $\mathrm{SH}_{\mathrm{dv}}$ tephra.

Site 5 consists of 45 depressions on a series of ridges overlooking the lake. Most of the depressions are large and square and represent a Late Neolithic occupation. There are a few small shallow depressions with occupation layers found between 4500 and $1700 \mathrm{cal}$ BP. 
Site 6 contained a line of 16 dwelling depressions on separate low hill tops at a point that appears to have once been at the confluence of a large river emptying into Lake Kultuchnoye. The main cluster of depressions found close to the lake contained large and very deep depressions with occupation layers that fall between 1400 to 500 cal BP. A smaller cluster of three shallow depressions was identified that contained occupation surfaces below the $\mathrm{KS}_{1}$ tephra.

\subsubsection{Summer Camp Lake}

The Summer Camp Lake area was intensively surveyed in 2010 and 2011. A total of eight sites were found in 2010 near the mouth of the Kamchatka River. Four more were identified in 2011. Most of the depressions found at the sites were relatively dated as falling between the Middle and Late Neolithic periods (3000-500 cal BP). A few smaller sites were relatively dated to approximately $4000-5000 \mathrm{cal}$ BP. This area seems to be the most intensively occupied of the areas investigated during the project.

In 2010 a 1x2 $\mathrm{m}$ trench was excavated in one of the dwelling depressions of Site 3. The excavation showed that the dwelling was occupied for a short period which occurred significantly before the $\mathrm{SH}_{\mathrm{dv}}$ tephra fall. The occupation ended with the burning of the pit house roof. These well-preserved beams were found to be intact on the floor of the dwelling.

In 2011, a second, larger scale excavation took place at Site 3 at Summer Camp Lake. Four trenches were excavated on former dwelling depressions and adjacent areas buffering the depressions. Testing revealed the presence of multiple occupation layers across the site that preceded the $\mathrm{SH}_{\mathrm{dv}}$ event. Excavations identified numerous post holes, hearths, and in situ burnt structural features. Artifact material revealed a dense tool and flake assemblage between all trenches comprised of chalcedony, chert, obsidian, and basalt. Faunal material was less well preserved, however some small bird and mammal bones were identified. Site 3 can be characterized as a location that was habitually occupied starting from ca. 5000 cal BP. Its most recent occupation, found directly below the $\mathrm{SH}_{1450}$ tephra, suggests the site was permanently abandoned after the pit houses in the area excavated were destroyed by a fire. 


\subsubsection{Paleoshoreline Island 1}

The paleoshoreline Island 1 area was surveyed in 2010 and contained four sites. The largest site contained nearly 100 dwelling depressions and was the largest occupation identified during the project. Site 1 was inferred to be a relatively recent occupation dating to the Late Neolithic. Soil sampling of two nearby sites on adjacent higher terraces date to at least 4400 cal BP based on associated tephra layers.

\subsubsection{Paleoshoreline Island 2}

This area was surveyed in 2010 contained one site with 15 dwelling depressions. This site overlapped multiple periods with long, continuous Late Neolithic occupations that spanned from ca. 2500 to $500 \mathrm{cal}$ BP. $50 \times 50 \mathrm{~cm}$ shovel pit testing revealed a high artifact density.

\subsubsection{Paleoshoreline Island 3}

This area was surveyed in 2010 and contained one site comprised of a cluster of six depressions. Similar to the high elevation terraces in Paleoshoreline Island 1, 50x50 cm shovel pit testing revealed a short Middle Neolithic occupation (ca. 4400 cal BP) and a low artifact density.

\subsubsection{Paleoshoreline Foothills, High Elevation, and Near Coast}

In 2010, one site was identified in this survey area. It consisted of two depressions. Shovel testing and coring showed them to be the result of short Middle Neolithic occupation ca. 4400 cal BP.

No prehistoric sites were identified in the High Elevation survey area in 2010. Four sites were found in the Paleoshoreline Near Coast survey area in 2010. They ranged from large Late and remnant Neolithic sites found on the lower elevation terraces to small clusters of depressions dating to ca. $4400 \mathrm{cal} \mathrm{BP}$ on the higher terraces.

\subsubsection{Stolbovaia}


The Stolbavaia area was intensively surveyed in 2010 and contained 15 sites distributed along two differently elevated marine terraces. Twelve of these sites were located along the upper terrace and three along the lower terrace. Sites on both terraces consisted of clusters of dwelling depressions of varying size and depth. Depressions on the lower terrace tended to be small, shallow and were characterized as Middle to Late Neolithic occupations, while depressions on the upper terrace were larger, deeper and characterized as Early to Late Neolithic occupations. Sites on the upper terrace generally consisted of many more depressions than those on the lower terrace. Upper sites contained from three to twenty depressions per cluster, while lower sites contained between three to six depressions per cluster.

Site 1 was positioned on the seaward edge of the upper terrace above a ravine where a small stream runs north to the Bering Sea. It comprised a small group of three dwelling depressions. At Site 1, trench excavations were opened and revealed multiple occupation layers spanning the early Neolithic (ca. 3000 to $500 \mathrm{cal} \mathrm{BP}$ ). Over 900 artifacts were collected during testing and comprised a wide array of material types (Fig. 4). This site also yielded the overall project's oldest radiocarbon date of ca. 6,300 cal BP.

Sites 2 through 12 were subjected to shovel testing and soil probes. Testing and sampling revealed that many of the sites at Stolbovaia had occupations extending back as far as the $\mathbf{S H}_{\mathrm{dv}}$ event. Sites 13 through 15 on the lower terrace were more recent and appeared above the $\mathrm{SH}_{\mathrm{dv}}$ tephra in excavations. Large quantities of bone and shell were recovered above the $\mathrm{KS}_{1}$ tephra. Sites on the lower terrace were also found to have an abundance of debitage derived from low quality silicified igneous and sedimentary rock that was not present at sites on the upper terrace.

\subsubsection{Stolbovaia Lake}

The northeastern area of Stolbovaia Lake was surveyed in 2011 and contained seven sites, three along the lake shore and four on the river. These sites are characterized as both Middle and Late Neolithic occupations. Site 1 comprised a cluster of 13 depressions on a sloping terrace adjacent to a river outlet on Stolbovaia Lake. The depressions on the lower part of the terrace were shallow and contained occupation layers between that spanned between the $\mathrm{SH}_{\mathrm{dv}}$ and $\mathrm{KS}_{1}$ 
tephras. Depressions on the higher end of the terrace were large and deep Late Neolithic occupations.

Sites 2, 3 and 4 both consisted of small clusters of depressions on a low terrace facing a stream that emptied into Stolbovaia Lake. Depressions were shallow with occupation layers mixed with $\mathrm{KS}_{1}$ tephra. Site 5 and 6 both consisted of a small cluster of depressions in a row along three terraces adjacent to the river. The depressions are a mix of large deep and shallow Middle to Late Neolithic occupations with cultural layers found below the $\mathrm{KS}_{1}$ tephra.

Site 7 comprised a cluster of seven depressions on a long narrow sloping ridge between the Stolbovaia River and an open grassy area that may have been a paleo-estuary. The dwelling depressions are shallow with cultural layers mixed with and below the $\mathrm{KS}_{1}$ tephra. Three of the depressions were found at an elevation of 65 meters asl at the very top of the ridge terrace.

\subsubsection{Paleoshoreline Island 4}

Paleoshoreline Island 4 area was surveyed in 2011 and contained one site with 16 depressions spread across several ridges approximately two kilometers from a nearby lake. Most of the depressions were shallow, roughly $8 \times 8$ meters in diameter and contained Middle Neolithic occupation layers below the $\mathrm{KS}_{1}$ tephra. One shallow depression on the northeast side of the ridge contained a cultural layer mixed with or below the $\mathrm{SH}_{\mathrm{dv}}$ tephra.

\subsubsection{Summary}

Over 4,000 artifacts were collected during testing and excavations performed between 2009 and 2011. Figure 5 lists comparative distributions of stone tools and artifacts found between Izvelisty, Kultuk, Stolbovaia and Summer Camp Lake survey areas. Tools categories included hammerstones, groundstone cobbles, adzes, prismatic blades, scrapers, projectile points and bifacial cores. At Stolbovaia, a obsidian seal effigy and labret were also recovered. Lithic debitage is not included in the figure due to the large number of flakes collected $(N=1,094)$. Proportionally, the greatest number of flakes came from Stolbovaia $(n=720)$, followed by Izvelisty ( $n=194)$, Summer Camp Lake ( $n=154)$ and Kultuk $(n=26)$. 
In Kamchatka, osteological preservation is extremely poor. Of the four sites listed above, Stolbovaia produced the greatest number $(N=84)$ of bones and bone fragments. The material collected was unidentifiable in the field and is currently being analyzed by the project's Russian partners.

Table 4 lists comparative lithic types of artifacts recovered from four major survey areas. This table illustrates that during the middle to Late Holocene, raw materials used in tool manufacture were highly variable in the Ust-Kamchatsk region. However it is important to note that some sample bias may be present by the fact that intensive excavations at Stolbavaia in 2010 over a proportionally larger surface area may have resulted in a skewed representation of the amount of artifacts recovered.

Proportions of raw material within and between study areas (particularly the Stolbavaia locale) are indicative of variability in material use over the landscape. The large proportion of silicified igneous or sedimentary rock artifacts recovered at Stolbavaia suggests the major exploitation of these material types during the Late Neolithic. These low quality materials are not well suited to tool manufacture and may reflect a period of resource scarcity at differing times over the last three millennia. Such scarcity may have arisen from economic disruptions after the $\mathrm{KS}_{1}$ event. This pattern was not observed in other study areas and further research on lithic sourcing in the region may shed light on this initial observation.

The cultural chronology of this region is not fully resolved. However, a few new generalizations are possible based on the data gathered between 2009 and 2011. In the five locales (Izvelisty, Kultuk, Stolbovaia, Stolbovaia Lake and Summer Camp Lake) where intensive testing was conducted, most of the cultural material is found in the upper levels of the stratigraphy. Based on both ${ }^{14} \mathrm{C}$ and relative tephra dating of these survey locations, occupations can be subdivided into three main periods: (1) sites that span from 6300-3100 cal BP, (2) sites that span from 3100-1400 cal BP, and (3) sites that span from 1400-500 cal BP. For all areas surveyed and tested, there are long periods of cultural stability punctuated by large amounts of growth followed by abandonment. While re-occupation is observed in locales closer to the paleoshoreline and present day coast (e.g., Stolbovaia and Kultuk), occupations within the 
interior appear to decrease significantly over the middle to late Holocene. This pattern correlates significantly with the major $\mathrm{KS}_{1}$ event. The tephra fall resulting from the eruption at this time appears to have accelerated a large-scale settlement pattern change already occurring in the region by the onset of the middle Neolithic (ca. 4500 cal BP).

\subsection{Pollen evidence of tephra impact on the landscape}

Tephra falls frequently induce major vegetation changes across affected areas ranging from changes in species composition (Stott et al., 1998) to a more or less complete replacement of ecosystems (i.e., forest to grassland) (Pendea et al., 2013). High resolution pollen analysis from quality paleoenvironmental archives is one of the best ways to document these vegetation shifts. Pollen are extremely good indicators of environmental change across space as source areas range from local (within meters of the plant source) to regional (100 $\mathrm{km}$ or more around the sample site).

To illustrate the effect of tephra deposition on regional vegetation, pollen and spore percentages of selected taxa for $\mathrm{KS}_{1}$ and $\mathrm{SH}_{1964}$ tephra fall events are presented in Figures 6 and 7, respectively. The selected taxa are grouped between categories of "Trees", "Shrubs", "Herbs", and "Disturbance indicators" to allow for a simplified landscape characterization. The pollen diagrams follow the evolution of various taxa and taxa groups for several centuries prior to and after tephra deposition events.

The $\mathrm{KS}_{1}$ tephra eruption occurred ca. $1750 \mathrm{cal} \mathrm{BP}$ and caused a substantial reduction in forest species, indicated by a decrease in pollen frequency from ca. $40 \%$ to $10 \%$ for stone birch (Betula ermanii) and from $10 \%$ to $<1 \%$ for alder (Alnus incana-type). Simultaneously, herb species such as grasses (Poaceae) and sedges (Cyperaceae) increase considerably from $10 \%$ to $>20 \%$ of the total pollen spectra. Pollen frequencies of shrub taxa remain relatively unchanged, although larger shrubs such as Alnus fructicosa seem to decrease in importance while smaller shrubs such as dwarf birch (Betula nana/humilis-type) and bayberry (Myrica) show substantial increases several decades after the eruption. The appearance of Glomus fungal spore in frequencies of over $10 \%$ indicates significant soil erosion on hillslopes around the core site. The 
relative frequencies of trees, shrubs, herbs, and aquatics indicate that the eruption caused an opening of the landscape, with graminoids (grasses and sedges) replacing parts of the stone birch woodlands. Approximately a century after the eruption, the regional vegetation reverts to a species structure and abundance similar to that of the pre-eruption landscape.

The more recent deposition of $\mathrm{SH}_{1964}$ tephra offers the opportunity to study vegetation development following a volcanic eruption at a decadal scale due to fact that the peat deposited after this eruption is virtually uncompressed. Pollen and spore frequencies shifts following the $\mathrm{SH}_{1964}$ ash deposition show a broad similarity to that of $\mathrm{KS}_{1}$ eruption. Forest taxa show a general decline from $\sim 20 \%$ to $\sim 5 \%$. Forest decline was occurring prior to this eruption, possibly because of some earlier ash falls that were not clearly identified in the Krutoberegovo peat profile but widely known in the area (V. Ponomareva, personal communication).

Shrub taxa show a slight decrease, mainly because of a shift in Myrica pollen frequencies that decreases from $35 \%$ prior to the eruption to $5 \%$ around AD 2000. Of all major regional vegetation constituents, only grasses (Poaceae) show a net gain, from $<5 \%$ prior to the eruption to ca. $25 \%$ around $\mathrm{AD}$ 1990. The effects of the $\mathrm{SH}_{1964}$ eruption are more clearly expressed in changes to pollen and spore frequencies of disturbance indicators. For example, horsetails (Equisetum), which favor disturbed and bare mineral soils, show a marked increase in and around the Krutoberegovo fen after the $\mathrm{SH}_{1964}$ event. A sharp increase in microscopic charcoal and the appearance of Glomus spores, an erosion indicator, also suggests widespread landscape disturbance following the event. The pollen analysis of the top peat sample, representing the last 15 years, indicates a slight landscape recovery, with a modest increase of forest taxa and a decrease in grassland pollen. Disturbance indicators show also decreasing frequencies.

\section{Discussion}

\subsection{Exploring human response to tephra fall}

During the middle to late Holocene, recurrent ash falls had both short and long-term consequences for seasonally mobile hunter-gatherer populations living in Kamchatka. Similar ethnohistorical studies in neighboring coastal and insular environments, such as the Aleutian 
Island arc and the Kuril Islands emphasize the importance of understanding catastrophic landscape change in the North Pacific in relationship to human survival. Although research in the Kurils found no direct evidence for large scale adverse impacts from volcanic eruptions or tsunami (Fitzhugh, 2012), comparison between the Rat Islands in the Aleutians and the Kurils leaves open the possibility that human populations in the Kurils were more exposed and vulnerable to natural hazards in the form of volcanic eruptions and climate extremes. Higher archaeological site densities and apparently more continuous, long-term human occupation in the Rat Islands, especially settlements in close proximity to active volcanoes, suggest that human populations successfully negotiated volcanic events for millennia (Fitzhugh and Funk, 2015, personal communication). In the Kurils, population densities grew during the late Holocene, but experienced two declines. The first occurred ca. $1500 \mathrm{cal} \mathrm{BP}$, and again ca. $800 \mathrm{cal} \mathrm{BP}$. Both declines appear to be unrelated to volcanic forcing events. Fitzhugh (2012) suggests that in the Kuril context, volcanic eruptions may generally have supported human settlement by enhancing nutrient status and increasing biological productivity in nearshore marine systems.

Volcanic eruptions may drastically affect local environments in the short-term (Workman, 1979; Black, 1981) but also simultaneously improve plant and animal productivity over longer periods of time (Kurenkov, 1966; Workman, 1979; Lucht et al., 2002; Telford et al., 2004; Parsons and Whitney, 2012; Olgun et al., 2013). In lacustrine systems, tephra fallout can induce either an enhanced nutrient status or depress biota through the disruption of nutrient cycles and introduction of toxic compounds (Fazlullin et al., 2000; Telford et al., 2004). The long-term impact of tephra fallout on hydrological systems frequently extends beyond the period of eruption due to periodic contamination by runoff from ash-laden terrain (e.g., Whetstone, 1955; Telford et al., 2004). The increased productivity of lakes following a tephra fall can last as long as 15 years, while ecological impacts on lake ecosystems may linger for several decades (Telford et al., 2004).

The relationship between tephra fallout and major prehistoric food resources, such as salmon, are difficult to quantify. Ash falls lead to accelerated rates of erosion on hillslopes and increased deposition of sediment in river channels and valley floors. Shallow bodies of water 
may disappear entirely. These processes lead to the death of spawning salmon in ash choked streams and rivers (Eicher and Rounsefell, 1957; Kurenkov, 1966; Parsons and Whitney, 2012; Olgun et al., 2013). Tephra falls may have negative effects on salmon spawning patterns for as much as three to six years after an eruption depending on the spawning patterns of particular species (Eicher and Rounsefell, 1957; Kurenkov, 1966; Workman, 1979; Parsons and Whitney, 2012; Olgun et al., 2013).

In Kamchatka, human responses to these major environmental changes are most archaeologically visible in the form of major shifts in settlement patterning on the landscape. Based on the evidence collected between 2009 and 2011, we suggest that there is a marked difference in the settlement patterns found between temporal periods. There are also periods when the study area was more densely occupied. For example, the occupation surfaces of many sites lie under the $\mathrm{KS}_{1}$ and then appear to have been abandoned. Significant tephra falls over the Holocene may have had an effect on local ecosystems causing a change in the settlement patterns or a temporary abandonment. The following summary provides a thumbnail sketch of the major periods of occupation in the region and the characteristic patterning accompanying each temporal phase.

\section{$\underline{\text { 5.1.1. 6300-3100 cal BP }}$}

The earliest sites in the region were occupied after ca. $6300 \mathrm{cal}$ BP. The small temporary occupations of this time consisted of hearths with little or no lithic material, and in some cases burnt bone. These sites are interpreted as short-term hunting camps with some interrupted occupations that range from two to three thousand years (see Hulse et al., 2011). In some cases the dwelling depressions were continuous occupations span all three periods. The three oldest sites date to ca. 6300, 6100 and 5900 to $6200 \mathrm{cal} \mathrm{BP}$. Disturbed older sites were frequently found beneath younger occupation surfaces. These older period sites appear to have been chosen to exploit specific habitats (i.e. riverine, lacustrine, boreal forest, marine, etc.).

\subsubsection{0-1400 cal BP}


The most intensive occupations occurred between 3100 to 1400 cal BP (Fig. 8a). They usually consisted of round dwelling depressions, one to ten meters in diameter. These sites were probably seasonally occupied to exploit maritime resources during the winter and spring and to take advantage of terrestrial resources and salmon runs during the summer and fall. The majority of ${ }^{14} \mathrm{C}$ ages obtained for sites of this period range from 2600 to $1900 \mathrm{cal} \mathrm{BP}$.

A number of sites during this period contained occupation layers directly below the $\mathrm{KS}_{1}$ tephra layer. These sites may have been occupied anywhere from one season to decades before the eruption. Several other occupations are within a few centimeters below this $\mathrm{KS}_{1}$ tephra and ${ }^{14} \mathrm{C}$ dates indicate that they were primarily occupied between the period of 2600-1750 cal BP. Most of these sites were not reoccupied after the eruption although a few do contain thin charcoal layers directly above the $\mathrm{KS}_{1}$ tephra layer. It is not possible to determine the exact extent of occupations that followed the $\mathrm{KS}_{1}$ eruption because in most cases the tephra layer would have been disturbed in the later construction and reoccupation of the pit houses. This is demonstrated by the fact that many of this period contained occupation surfaces mixed $\mathrm{KS}_{1}$ tephra. These could either have been occupied any time after or during the eruption. At least one site excavated extensively Stolbovaia contained an occupation surface mixed with $\mathrm{KS}_{1}$ tephra. This may indicate that the site was occupied through the $\mathrm{KS}_{1}$ event.

\subsubsection{0-500 cal BP}

Late period sites are typically large, permanent coastal settlements and seasonal dwellings found in proximity to salmon spawning grounds in rivers, lakes and the late Holocene paleoshoreline (Fig. 8b). Sites from this time period consist of up to 15 or more square dwelling depressions typically 10 to $15 \mathrm{~m}$ in diameter and over $1 \mathrm{~m}$ deep. Frequently, smaller adjacent pits are observed connected to the larger pits. These smaller pits may have served as anti-chambers or storage areas for the dwellings.

\subsection{Continuity and change}


Observing all three periods together, there is a general trend from seasonal sites to permanent coastal sites and a greater reliance on marine resources throughout the region. Initial evidence suggests the region experienced a demographic shift marked by the aggregation of smaller, dispersed pit-house clusters to larger more densely populated settlements starting ca. 3100 cal BP and continuing to ca. 500 cal BP. Thirty-two of the 60 sites investigated between 2009 and 2011 were occupied in the 700 year period before the $\mathrm{KS}_{1}$ tephra fall. Seventeen of these sites had occupations that fell directly under the tephra layer. Thirteen sites were occupied in the 350 year period following the $\mathrm{KS}_{1}$ eruption (Fig. 9). The chronology of the later sites were wellconstrained by the presence of the $\mathrm{SH}_{1450}$ tephra marker.

Fig. 10 shows the linear regression of the number of sites leading up to and directly after the $\mathrm{KS}_{1}$ event in relationship to major changes occurring on the landscape ca. 2225 to 1410 cal BP. Although the physical impact of tephra deposition from $\mathrm{KS}_{1}$ may have been minimal on human populations, pollen evidence unequivocally demonstrates that the landscape within the fallout area drastically changed. In the decades after the event, the ecological stress resulting from the massive tephra fall resulted in a substantial die out of stone birch forest woodlands and an opening of the landscape to grasslands and shrubberies. This landscape change may have shifted resource type and availability for prehistoric communities previously dependent on forest subsistence base.

Although the $\mathrm{KS}_{1}$ event may not have been enough to permanently shift the subsistence pattern seen in the Late Holocene by itself, a dramatic decrease in forest cover resulting from the eruption could have strongly encouraged people during this time to shift away from terrestrial game to other more seasonally dependable food sources. The $\mathrm{KS}_{1}$ eruption occurred during a gradual aggregation of communities into larger and perhaps more densely populated permanent coastal sites along major rivers and lakes in the region. This is indicated by the fact that there are far fewer inland sites occupied along smaller streams and rivers in the period after the $\mathrm{KS}_{1}$ eruption as compared to the period before. The cooling climate at this time may have also led to an increasing focus on marine mammal hunting observed throughout the Russian Far East ca. 1500 cal BP (Kuzmin, 2008). In this context, the $\mathrm{KS}_{1}$ event may have been a catalyst for the 
settlement shift by limiting the supply of terrestrial resources for an extended period of time after the $\mathrm{KS}_{1}$ event.

Seasonal timing of the ash fall is relevant in determining both the environmental and cultural effects on human populations. If the ash fell on snow during the winter months it may have initiated an early spring while a deep ash fall may conversely insulate and preserve snow for several years in low altitudes (Workman, 1979). There is some indication that the Ksudach eruption occurred during the winter. Site 1 excavated at Stolbovaia appeared characteristic of a winter settlement. This site is adjacent to a river outlet that in recent times contains a large modern seal population and is a popular area for modern residents of Ust-Kamchatsk to ice fish for smelt during the winter months. Analysis of the $\mathrm{KS}_{1}$ tephra $\mathrm{f}$ indicated a complete lack of airborne pollen and spores and gives strong support to a winter deposition.

It appears the people occupying the Kamchatka peninsula negotiated the environmental impacts of the $\mathrm{KS}_{1}$ ash fall because they were already in a transition period at the time of the eruption (i.e. greater reliance on marine and aquatic resources and less reliance on inland terrestrial resources). This may reflect a pattern seen in other coastal Pacific contexts where resource rich aquatic environments (e.g. rivers with annual salmon runs) provided a surplus subsistence base that afforded people to stockpile and live in sedentary or seasonally sedentary communities. Larger Late Neolithic occupations are identified before and after the $\mathrm{KS}_{1}$ event along tributaries near the Kamchatka River that are known to support salmon spawning.

Sheets (2007), in exploring human responses to volcanic events in Central America has offered that non-agrarian egalitarian societies with low population densities exhibit the greatest resilience to sudden massive volcanic stresses. However Torrence et al. (2009) refute this argument. Based on studies of small mobile populations in Papua New Guinea, they suggest that flexible subsistence and long-distance social ties are in fact not a response but a long-term adaptive response to unstable volcanic environments. The relative frequency of disasters keeps populations low because these regions are periodically abandoned. These societies adopted subsistence and settlement patterns that enable them to return and reoccupy quickly after an event, for example by targeting areas least affected by tephra falls. 
Hulse et al. (2011) have observed that this quick reoccupation after abandonment is reflected in the higher elevation of some sites, particularly in the Kultuk area. This may be due to the fact that high points experience tephra erosion due to the high annual rainfall. Present-day coastal Kamchatka receives 2,500 mm of precipitation annually, and it is likely that high places would experience rapid and significant ash clearance (Solomina et al., 2007). They also suggest that high precipitation has consequences apart from washing the terrain--heavy metals from volcanic ash are often leached out by rainfall and may contaminate water supplies (Witham et al., 2005).

\section{Conclusions}

While a direct causal relationship between the $\mathrm{KS}_{1}$ event and a change in settlement in the late Holocene cannot be assumed, there is ample paleoenvironmental evidence to suggest rapid and dynamic changes occurred to the region's birch forest woodland ecosystem. We suggest that these changes contributed to a greater reliance on marine resources by prehistoric human populations in the region and this is demonstrated by the significant realignment in settlement locales from the interior to lacustrine, lagoonal and coastal settings. Relative dating of the occupations in relation to the tephra layers indicates a significant shift in human settlement patterns that correspond to both short and long-term localized environmental changes. Future comparative analyses of faunal material found within archaeological contexts could greatly improve upon testing this hypothesis.

While volcanic activity has been extensively researched for several decades in the Kamchatka peninsula, intensive archaeological research has been lacking. Most of the largescale archaeological surveys took place in the 1960s through 1980s when the age of most tephra layers was unknown.There is little reference to the tephra layers in archaeological reports from this time and relationships to the various eruptions can only be inferred. This is compounded by the fact that concerns have been raised about the comparability of some ${ }^{14} \mathrm{C}$ dates obtained during this past few decades (Geobel, 2003). 
At the moment, additional high resolution radiocarbon dates are needed to reconstruct an occupation history that illustrates the full correlation between major tephra falls and changing settlement patterns in Kamchatka. Further archaeological work could also shed light on the wider regional impacts of both affected and non-affected areas in order to determine if there was population movement from the affected area at the time of the $\mathrm{KS}_{1}$ eruption.

Since most of the recent archaeological research in Kamchatka has taken place in the area covered by the $\mathrm{KS}_{1}$ event, it is difficult to determine the full extent of population movement outside of the affected area to the far south, the northeast coast or the unaffected west coast of the peninsula. The $\mathrm{KS}_{1}$ event had a negligible impact on the Kuril Islands. It is possible that following the event there could have been an initial population movement to the southern tip of Kamchatka and on into the Kuril Islands (Fitzhugh, 2015, personal communication). The need for further data presents itself as a promising avenue of future interdisciplinary research and may help to provide further insight into human responses to volcanic events and their relationship to coastal adaptations in the North Pacific during the Holocene.

\section{Acknowledgments}

The other authors would like to thank the P.I of the ICCAP project, Professor Ezra Zubrow as well as the other the senior researchers: Irina Ponkratova, Dustin Keeler, Gregory Korosec, Tatiana Pinegina and Eva Hulse. Special thanks to V. Ponomareva, M. Pevzner and J. Bourgeois for their help with tephrochronology. We would also like to thank the National Science Foundation for funding the ICCAP project (Division of Polar Programs, Arctic Social Sciences grant, Award Number: 0915131- International Collaborative Circumpolar Archaeological Project (ICCAP): Joint Russian-American research in Kamchatka). Our sincerest gratitude to all our American and Russian colleagues, post-doctoral scholars, graduate and undergraduate students involved in the lab and field work for this project.

\section{References}


Ackerman, R. E., 1998. Early maritime traditions in the Bering, Chukchi and East Siberian Seas. Arctic Anthropology, 247-262.

Adams, R. M., 1978. Strategies of Maximization, Stability, and Resilience in Mesopotamian Society, Settlement, and Agriculture. Proceedings of the American Philosophical Society 122(5), 329-335.

Antos, J. A., Zobel, D. B., 1985. Plant form, developmental plasticity, and survival following burial by volcanic tephra. Canadian Journal of Botany 63(12), 2083-2090.

Bäumler, R., Zech, W., 2000. Quaternary paleosols, tephra deposits and landscape history in South Kamchatka, Russia. Catena 41(1-3), 199-215.

Begét, J., Gardner, C., Davis, K., 2008. Volcanic Tsunamis and Prehistoric Cultural Transitions in Cook Inlet, Alaska. Journal of Volcanology and Geothermal Research 176 (3), 377-386.

Black, L. T., 1981. Volcanism as a factor in human ecology: The Aleutian case. Ethnohistory 28(4), 313-340.

Blackmore, S., Steinmann, J. A., Hoen, P. P., Punt, W. 2003. Betulaceae and Corylaceae. Review of Palaeobotany and Palynology 123(1), 71-98.

Bourgeois, J., Pinegina, T. K., Ponomareva, V., Zaretskaia, N., 2006. Holocene tsunamis in the southwestern Bering Sea, Russian Far East, and their tectonic implications. Geological Society of America Bulletin 118(3-4), 449-463.

Braitseva, O. A., Litasova, S. N., Sulerzhitsky, L. D., 1992a. Validity of radiocarbon dating in regions of active volcanism in Kamchatka. Quaternary International 13, 143-146.

Braitseva, O. A., Melekestsev, I. V., Ponomareva, V. V., Kirianov, V. Y., Litasova, S. N., Sulerzhitsky, L. D., 1992b. Tephra of the largest prehistoric Holocene volcanic eruptions in Kamchatka. Quaternary International, 13, 177-180.

Braitseva, O. A., Melekestsev, I. V., Ponomareva, V. V., Kirianov, V. Y., 1996. The calderaforming eruption of Ksudach volcano about Cal. AD 240: the greatest explosive event of our era in Kamchatka, Russia. Journal of Volcanology and Geothermal Research 70(1), 49-65.

Braitseva, O. A., Ponomareva, V. V., Sulerzhitsky, L. D., Melekestsev, I. V., Bailey, J., 1997. Holocene key-marker tephra layers in Kamchatka, Russia. Quaternary Research 47(2), 125-139. 
Clark, D. W., 2001. Microblade-culture systematics in the far interior northwest. Arctic Anthropology 38(2), 64-80.

Derevianko, A. P., Kuzmin, Y. V., Burr, G. S., Jull, A. J. T., Kim, J. C., 2004. AMS 14 C age of the earliest pottery from the Russian Far East: 1996-2002 results. Nuclear Instruments and Methods in Physics Research Section B: Beam Interactions with Materials and Atoms 223, 735739.

Dikov, N. N., 1965. The Stone Age of Kamchatka and the Chukchi Peninsula in the light of new archaeological data. American Antiquity 111(1), 10-25.

Dikov, N. N., 1977. Arkheologicheskie pamyatniki Kamchatki, Chukotki i Verkhnei Kolymy (Aziya na styke s Amerikoi v drevnosti) [Archaeological Sites of Kamchatka, Chukotka, and the Upper Kolyma (Asia at the Crossroads with America in Antiquity)]. Moscow. [English translation: Archaeological Sites of Kamchatka, Chukotka, and the Upper Kolyma. Beringian Shared Heritage Program. Anchorage, Alaska: National Park Service. 2003.]

Dikov, N. N., 1983. Stages and routes of human occupation of the Beringian land bridge based on archaeology data. In: Masters, P. M., Flemming, N. C. (Eds.), Quaternary Coastlines and Marine Archaeology: Towards the Prehistory of Land Bridges and Continental Shelves. Academic Press, London, pp. 347-364.

Dikov, N. N., 2003 [1977]. Archaeological sites of Kamchatka, Chukotka, and the Upper Kolyma. Translated by R. L. Bland. U.S. Dept. of the Interior, National Park Service, Shared Beringian Heritage Program, Anchorage, Alaska.

Dikova, T. M., 1983. Arheologiya Yuzhnoi Kamchatki (v svayazi s ainskoyi problemoi). Nauka, Moscow.

Dilehay, T.D., Kolata A.L., 2004. Long-term human response to uncertain environmental conditions in the Andes. PNAS 101(12), 4325-4330.

Eicher Jr, G. J., Rounsefell, G. A., 1957. Effects of lake fertilization by volcanic activity on abundance of salmon. Limnology and Oceanography, 70-76.

Faegri, K., Kaland, P. E., Krzywinski, K., 1989. Textbook of pollen analysis (Ed. 4). John Wiley \& Sons Ltd., Chichester. 
Fazlullin, S. M., Ushakov, S. V., Shuvalov, R. A., 2000. The Underwater Eruption in the Akademii Nauk Caldera, Kamchatka and Its Impact: Hydrologic, Hydrochemical, and Hydrobiological Investigations, Vulkanol. Vulkanol. Seismol 4, 19-32.

Finsinger, W., Tinner, W., 2005. Minimum count sums for charcoal concentration estimates in pollen slides: accuracy and potential errors. The Holocene 15(2), 293-297.

Fitzhugh, B., 2012. Hazards, impacts, and resilience among hunter-gatherers of the Kuril Islands. In: Cooper, J., Sheets, P., (Eds.) Surviving Sudden Environmental Change. University of Colorado Press, Boulder, pp. 19-42.

Folke, C., 2006. Resilience: The emergence of a perspective for social-ecological systems analyses. Global Environmental Change 16, 253-267.

Fritz, C. E. 1968. Disasters. In: Stills, D.L. (Eds.) The International Encyclopedia of the Social Sciences, Vol. 4., Macmillan Company and the Free Press, New York, pp. 202-207.

Galipaud, J-C., 2002. Under the volcano: Ni-Vanuatu and their environment. In: R. Torrence and J. Grattan (eds.), Natural Disasters and Cultural Change, Routledge, London, pp. 162-171

Godelman, Y. M., Pugayev, A. N., 1976. Heterogeneity of Soil Cover in Central and Southeastern Kamchatka. Soviet Soil Science 8(6), 641-650.

Goebel, T., Waters, M. R., Dikova, M., 2003. The archaeology of Ushki Lake, Kamchatka, and the Pleistocene peopling of the Americas. Science 301(5632), 501-505.

Grattan, John. 2006. Aspects of Armageddon: An Exploration of the Role of Volcanic Eruptions in Human History and Civilization. Quaternary International 151 (1), 10-18.

Hall, M. L., Mothes, P. A., 2008. Volcanic Impediments in the Progressive Development of preColumbian Civilizations in the Ecuadorian Andes. Journal of Volcanology and Geothermal Research 176 (3), 344-355.

Hegmon, M., Peeples, M. A., Kinzig, A. P., Kulow, S., Meegan, C. M., Nelson, M. C., 2008. Social transformation and its human costs in the prehispanic US Southwest. American Anthropologist 110(3), 313-324. 
Hulse, E., Keeler, D., Zubrow, E., Korosec, G., Ponkratova, I., Curtis, C., 2011. Preliminary report on archaeological fieldwork in the Kamchatka region of Russia. Sibirica: Interdisciplinary Journal of Siberian Studies 10(1), 48-74.

Jones, V., Solomina, O., In Press. The geography of Kamchatka. Global and Planetary Change.

Kapp, R.O., Davis, O.K., King, J.E., 2000. Ronald O. Kapp's Pollen and Spores, second edition. American Association of Stratigraphic Palynologists.

Knecht, R. A., Davis, R. S., 2008. The Amaknak Bridge Site: cultural change and the Neoglacial in the Eastern Aleutians. Arctic Anthropology 45(1), 61-78.

Kozhurin, A. I., Pinegina, T. K., Ponomareva, V. V., Zelenin, E. A., Mikhailyukova, P. G. 2014. Rate of collisional deformation in Kamchatsky Peninsula, Kamchatka. Geotectonics 48(2), 122138.

Krasheninnikov, S. P. 1972 [1942]. Opisanie Zemli Kamchatki [Description of the Land of Kamchatka]. Moscow-Leningrad. [English translation: Explorations of Kamchatka, 1735-1741. Portland: Oregon Historical Society.].

Krestov, P.V., Omelko, A.M., Nakamura, Y., 2008. Vegetation and natural habitats of Kamchatka. Ber. d. Reinh.-Tüxen-Ges. 20, 195-218.

Kurenkov, I. I., 1966. The influence of volcanic ashfall on biological processes in a lake. Limnology and Oceanography 11(3), 426-429.

Kuzmin, Y. V., 2000. Radiocarbon chronology of the stone age cultures on the Pacific coast of Northeastern Siberia. Arctic Anthropology 37(1), 120-131.

Kuzmin, Y. V., 2008. Geoarchaeology of prehistoric cultural complexes in the Russian Far East: recent progress and problems. Bulletin of the Indo-Pacific Prehistory Association 28, 3-10.

Kuzmin, Y. V., Orlova, L. A., 2000. The neolithization of Siberia and the Russian Far East: radiocarbon evidence. Antiquity 74(284), 356-364.

Kuzmin, Y. V., Speakman, R. J., Glascock, M. D., Popov, V. K., Grebennikov, A. V., Dikova, M. A., Ptashinsky, A. V., 2008. Obsidian use at the Ushki Lake complex, Kamchatka Peninsula (Northeastern Siberia): implications for terminal Pleistocene and early Holocene human migrations in Beringia. Journal of Archaeological Science 35(8), 2179-2187. 
Kyle, P. R., Ponomareva, V. V., Rourke Schluep, R., 2011. Geochemical characterization of marker tephra layers from major Holocene eruptions, Kamchatka Peninsula, Russia. International Geology Review 53(9), 1059-1097.

Lebedintsev, A. I., 1998. Maritime cultures of the north coast of the Sea of Okhotsk. Arctic Anthropology 35(1), 296-320.

Lowe, D. J., Newnham, R. M., McFadgen, B. G., Higham, T. F. G., 2000. Tephras and New Zealand Archaeology. Journal of Archaeological Science 27 (10), 859-870.

Lucht, W., Prentice, I. C., Myneni, R. B., Sitch, S., Friedlingstein, P., Cramer, W., Smith, B. 2002. Climatic control of the high-latitude vegetation greening trend and Pinatubo effect. Science 296(5573), 1687-1689.

McCartney, A. P., Okada, H., Okada, A., Workman, W. B., 1998. North Pacific and Bering Sea maritime societies - The archaeology of prehistoric and early historic coastal peoples Introduction. Arctic Anthropology 35(1), 1-5.

Moore, P. D., Webb, J. A., Collison, M. E., 1991. Pollen analysis. Blackwell scientific publications, Oxford.

Neall, V. E., Wallace, R. C., Torrence, R., 2008. The Volcanic Environment for 40,000 Years of Human Occupation on the Willaumez Isthmus, West New Britain, Papua New Guinea. Journal of Volcanology and Geothermal Research 176 (3), 330-343.

Newell, J., 2004. The Russian Far East: A reference guide for conservation and development. Daniel and Daniel, McKinleyville, CA.

Olgun, N., Duggen, S., Langmann, B., Hort, M., Waythomas, C. F., Hoffmann, L., Croot, P., 2013. Geochemical evidence of oceanic iron fertilization by the Kasatochi volcanic eruption in 2008 and the potential impacts on Pacific sockeye salmon. Marine Ecology Progress Series 488, 81-88.

Orekhov, A. A., Bland, R. L., Gokhman, A., Workman, W., Workman, K., 1998. The development of maritime adaptations among the early populations of the northwest Bering Sea region. Arctic Anthropology 35(1), 263-280. 
Ort, M. H., Elson, M. D., Anderson, K. C., Duffield, W. A., Samples, T. L., 2008. Variable Effects of Cinder-Cone Eruptions on Prehistoric Agrarian Human Populations in the American Southwest. Journal of Volcanology and Geothermal Research 176 (3): 363-376.

Ovsyannikov, A. A., Manevich, A. G., 2010. The October 2010 Eruption of Sheveluch Volcano. Bulletin of Kamchatka Regional Association "Educational-scientific center". Earth Sciences 16(2), 7-9.

Parsons, T. R., Whitney, F. A., 2012. Did volcanic ash from Mt. Kasatoshi in 2008 contribute to a phenomenal increase in Fraser River sockeye salmon (Oncorhynchus nerka) in 2010? Fisheries Oceanography 21(5), 374-377.

Peeples, M. A., Barton, C. M., Schmich, S., 2006. Resilience lost: Intersecting land use and landscape dynamics in the prehistoric southwestern United States. Ecology and Society 11(2), 18.

Pendea, I.F., Ponomareva, V., Bourgeois, J., Korosec, G., LaSelle, S-P., Ponkratova, I., Ferguson, C., Fraser, R., Keeler D., and Zubrow E., 2012. Late Glacial to Holocene Environmental History of eastern Kamchatka Peninsula, North Pacific. Geological Association of Canada Conference. St John's, NL.

Pendea, I.F., Ponomareva, V., McLeod, K., 2013. Disaster aftermath - decoding landscape and ecosystem responses to large-scale explosive volcanism. Joint meeting of the American Association of Stratigraphic Palynologists, North American Micropaleontology Section - SEPM, Canadian Association of Palynologists, DINO 10, and CIMP. San Francisco, CA.

Pevzner, M.M., Ponomareva, V.V., and Melekestsev, I.V., 1998. Chernyi Yar-Reference section of the Holocene ash markers at the northeastern coast of Kamchatka. Volcanology and Seismology 19, 389-406.

Pinegina T. K., Kozhurin A. I., Ponomareva V. V. 2012. Seismic and tsunami hazard assessment for Ust'-Kamchatsk settlement, Kamchatka, based on paleoseismological data. Bulletin of Kamchatka Regional Association "Educational-scientific center". Earth Sciences 19 (1), 138-159 [In Russian] . 
Pinegina, T. K., Bourgeois, J., Kravchunovskaya, E. A., Lander, A. V., Arcos, M. E., Pedoja, K., MacInnes, B. T. 2013. A nexus of plate interaction: Vertical deformation of Holocene wave-built terraces on the Kamchatsky Peninsula (Kamchatka, Russia). Geological Society of America Bulletin, 125(9-10), 1554-1568.

Pinegina T. K., Kozhurin A. I., Ponomareva V. V. 2014. Active tectonics and geomorphology of the Kamchatsky Bay coast in Kamchatka. Russian Journal of Pacific Geology 8(1), 65-76 Ponomarenko, A. K., 1985. Ancient Cultures of the East Kamchatka Itelmen. Nauka, Moscow. Ponomarenko, A. K., 2000. Drevniaia Kul'tura itel'menov Kamchatki, PetropavlovskKamchatskiı̌.

Ponomareva V., Blaauw M., Portnyagin M., Keeler D., Zubrow E., Korosec G., Hulse E., Bourgeois J., Ponkratova I. 2012. Detailed tephrochronological framework for archaeological sites in northeastern Kamchatka (Russia): better timing of distal tephra layers through correlation with proximal volcanic deposits. Tephra and archaeology: chronological, ecological, and cultural dimension. 18th Annual Meeting of the European Association of Archaeologists (EAA), Helsinki, Finland, August 29- September 1, 2012

Ponomareva V., Portnyagin M., Derkachev A., Pendea I.F., Bourgeois J., Reimer P. J., GarbeSchönberg D., Krasheninnikov S., Nürnberg D. 2013. Early Holocene M 6 explosive eruption from Plosky volcanic massif (Kamchatka) and its tephra as a link between terrestrial and marine paleoenvironmental records. International Journal of Earth Science 102(6), 1673-1699.

Ponomareva V., Portnyagin M., Pevzner M., Blaauw M., Kyle P., Derkachev A. 2015. Tephra from andesitic Shiveluch volcano, Kamchatka, NW Pacific: Chronology of explosive eruptions and geochemical fingerprinting of volcanic glass. International Journal of Earth Sciences. DOI 10.1007/s00531-015-1156-4

Ponomareva V., Portnyagin M., Pendea I.F., Bourgeois J., Pinegina T. K., Kozhurin A. I., Zubrow E. (in prep) A tephrochronological lattice for Holocene deposits of the Kamchatsky Peninsula (northeast Kamchatka, NW Pacific)

Ponomareva, V., Churikova, T., Melekestsev, I., Braitseva, O., 2007. Late Pleistocene-Holocene Volcanism on the Kamchatka Peninsula, Northwest Pacific Region. In: Eichelberger, J. C., 
Gordeev, E., Kasahara, M., Izbekov, P., Lees, J. (Eds.),Volcanism and Subduction : The Kamchatka Region. Geophysical monograph series 172. American Geophysical Union, Washington, DC., pp. 165-198.

Punt, W., Hoen, P. P., 2009. The Northwest European Pollen Flora, 70: SteraceaeAsteroideae. Review of Palaeobotany and Palynology 157(1), 22-183.

Savinetsky, A. B., Kiseleva, N. K., Khassanov, B. F., 2004. Dynamics of sea mammal and bird populations of the Bering Sea region over the last several Millennia. Palaeogeography, Palaeoclimatology, Palaeoecology 209, 335-352.

Sheets, P., 2007. People and volcanoes in the Zapotitan Valley, El Salvador. In: Grattan, J., Torrence, R., (Eds.), Under the shadow: The cultural impacts of volcanic eruptions. Left Coast Press, Walnut Creek, California, pp. 67-89

Slobodin, S., 2001. Western Beringia at the end of the ice age. Arctic Anthropology 38(2), 3147.

Solomina, O., Wiles, G., Shiraiwa, T., d'Arrigo, R., 2007. Multiproxy Records of Climate Variability for Kamchatka for the Past 400 Years" Climate of the Past 3(1), 119-128.

Steller, G. V. 1999. Opisanie zemli Kamchatki [English translation: Description of the Land of Kamchatka]. Petropavlovsk-Kamchatski.

Stockmarr, J., 1977. Tablets with spores used in absolute pollen analysis. Pollen Spores 13, 615621.

Stott, P., Horrocks, M., Ogden, J. 1998. The effects of the Taupo Tephra eruption of c. 1718 BP on the vegetation of Mt Hauhungatahi, central North Island, New Zealand. Journal of Biogeography 25(4), 649-660.

Stuiver, M., Reimer, P. J., Reimer, R. W. 2005. CALIB 5.0. [WWW program and documentation].

Telford, R. J., Barker, P., Metcalfe, S., Newton, A. 2004. Lacustrine responses to tephra deposition: examples from Mexico. Quaternary Science Reviews 23, 2337-2353.

Tinner, W., Hu, F. S., 2003. Size parameters, size-class distribution and area-number relationship of microscopic charcoal: relevance for fire reconstruction. The Holocene 13(4), 499-505. 
Torrence, R., Neall, V., Boyd, W. E., 2009. Volcanism and Historical Ecology on the Willaumez Peninsula, Papua New Guinea. Pacific Science 63(4), 507-535.

Vanderhoek, R., Nelson, R. E. 2007. Ecological roadblocks on a constrained landscape: The cultural effects of catastrophic Holocene volcanism on the Alaska Peninsula, southwest Alaska. In, Grattan, J., Torrence, R. (Eds.) Living Under The Shadow. Cultural Impacts of Volcanic Eruptions. Left Coast Press, Walnut Creek, CA, pp. 133-152.

Vasil'evskii, R. S., 1998. Fishing as an early form of maritime adaptation on the Pacific coast of Northeast Asia. Arctic Anthropology 35(1), 281-295.

Vereschagin, N.K., Nikolaev, A.I., 1979. Promyslovye zhivotnye u neoliticheskikh plemen Kamchtki [English translation: Hunting animals of neolithic tribes of Kamchatka] Bulletin MOIP, 84 (5) (1979), pp. 40-44 (in Russian)

Volynets, O. N., Ponomareva, V. V., Babansky, A. D., 1997. Magnesian basalts of Shiveluch andesite volcano, Kamchatka. Petrology 5(2), 183-196.

Watts, M., 1983: On the poverty of theory: natural hazards research in context. In: Hewitt, K., Interpretations of calamity. Allen and Unwin, London, pp. 231-262.

Whetstone, G.W., 1955. Effects of volcanic ash from Mt. Spurr on the chemical character of surface waters near Anchorage, Alaska (Abstract). Geological Society of America Bulletin 66, 1709.

Witham, C. S., Oppenheimer, C., Horwell, C. J., 2005. Volcanic AshLeachates: A Review and Recommendations for Sampling Methods. Journal of Volcanology and Geothermal Research 141, 299-326.

Workman, W. B., 1979. The significance of volcanism in the prehistory of subarctic northwest North America. Volcanic Activity and Human Ecology 339-71.

Workman, W. B., McCartney, A. P., 1998. Coast to coast: Prehistoric maritime cultures in the North Pacific. Arctic Anthropology 35(1), 361-370.

Zakharikhina, L. V., 2006. Soil formation on acid and basic volcanic ashes of different ages in Kamchatka. Eurasian Soil Science 39(9), 938-952. 


\section{Captions}

Figure 1. Kamchatka (Kamchatsky Krai, Russian Federation) with distribution of currently active volcanoes found on the peninsula. The 2009 -2011 ICAAP research project was conducted in the Ust-Kamchatsk region on the eastern coast. Inset shows location of Kamchatka peninsula in relation to Asian and North American continents. Volcanological data provided courtesy of the Smithsonian Global Volcanism Program and NOAA's National Geophysical Data Center.

Figure 2. 2009-2011 ICAAP project research area with locations mentioned in the text.

Figure 3. Isopach maps of illustrating two major tephra fall events in Kamchatka during the last 4700 years. The larger map shows the $\mathrm{KS}_{1}(1750 \mathrm{cal} \mathrm{BP})$ event and the smaller insert represents $\mathrm{SH}_{\mathrm{dv}}$ (4700 cal BP) event. The $\mathrm{KS}_{1}$ tephra is most widely dispersed, with a uniform thickness of $5-8 \mathrm{~cm}$, and is the most valuable tephrochronological markers in the study region.

Figure 4. Archaeological source materials were highly variable for the entirety of the Stolbavaia site complex (Kamchatsky Krai, Russian Federation). Of the total materials recovered ( $n=943)$, $37 \%(n=351)$ were silica or silica slate, $20 \%(n=184)$ were chert, $16 \%(n=152)$ were obsidian, $15 \%(n=142)$ were chalcedony, 9\% $(n=83)$ were bone, $3 \%(n=25)$ were granite, and <1\% was undifferentiated. Artifacts recovered included 720 flakes, 82 bone or shell fragments, 18 scrapers, 17 blades or knives, 16 projectile points, 15 adzes, 8 uncategorized bifaces, 8 hammerstones, 1 labret, and 1 animal effigy (seal). There also was 57 additional objects of likely cultural origin were undifferentiated.

Figure 5. Comparison of tool types and non-tool artifacts collected from Izvelisty, Kultuk, Stolbovaia and Summer Camp Lake survey areas.

Figure 6. Vegetation and landscape history before and after the $\mathrm{KS}_{1}$ tephra deposition derived from pollen, spores, and charcoal abundances recorded in peat sediments near Krutoberegovo, Kamchatsky Krai, Russian Federation. Selected pollen only. The summary diagram is based on the pollen and spore sum excluding Sphagnum spores and aquatics. Trees, shrubs, and charcoal are expressed as \% of tree and shrub sum. Other taxa are expressed as $\%$ of the main pollen sum. The charcoal signal is presented as the ratio of charcoal particles to the sum of tree and shrub pollen (\%). Clear curves represent 10 times exaggeration to enhance visibility of low abundance 
values. Chronological control is based on radiocarbon dates and an age-depth model presented in Pendea et al. (2012, 2013).

Figure 7. Vegetation and landscape history before and after the $\mathrm{SH}_{1964}$ tephra deposition derived from pollen, spores, and charcoal abundances recorded in peat sediments near Krutoberegovo, Kamchatsky Krai, Russian Federation. Selected pollen only. The summary diagram is based on the pollen and spore sum excluding Sphagnum spores and aquatics. Trees, shrubs, and charcoal are expressed as $\%$ of tree and shrub sum. Other taxa are expressed as $\%$ of the main pollen sum. The charcoal signal is presented as the ratio of charcoal particles to the sum of tree and shrub pollen (\%). Clear curves represent 10 times exaggeration to enhance visibility of low abundance values. Chronological control is based on radiocarbon dates and an age-depth model presented in Pendea et al. (2012, 2013).

Figure 8. Sites occupied in the 700 year period before and the 350 year period after the $\mathrm{KS}_{1}$ event. Dates are presented in ${ }^{14} \mathrm{C}$ age estimates. After the event there is a considerable shift of settlements from the interior to the paleoshoreline and coastal margins.

Figure 9. Number of sites occupied in the 7000 year period before and the 350 year period after the $\mathrm{KS}_{1}$ event.

Figure 10. Linear regression of the number of sites leading up to and directly after the $\mathrm{KS}_{1}$ event in relation to major environmental changes occurring on the landscape from ca. 2225 to 1410 cal BP.

Table 1. Radiocarbon dates for sites sampled in 2009 and 2010 in the study area (UstKamchatsk, Kamchatsky Krai, Russian Federation).

Table 2. Major Holocene marker tephra identified in archaeological excavations and test pits in the study area (Ust-Kamchatsk, Kamchatsky Krai, Russian Federation). Tephra layers are listed in stratigraphic order. Major markers are in bold. Tephra ages are from Braitseva et al., (1997), Pevzner et al., (1998), and Ponomareva et al., (2013, 2015).

Table 3. Numbers of sites identified in the surveyed areas by ICAAP between 2009 and 2011. In total, 60 prehistoric sites were documented during field surveys.

Table 4. Distribution of source materials in major ICAAP excavation areas. 

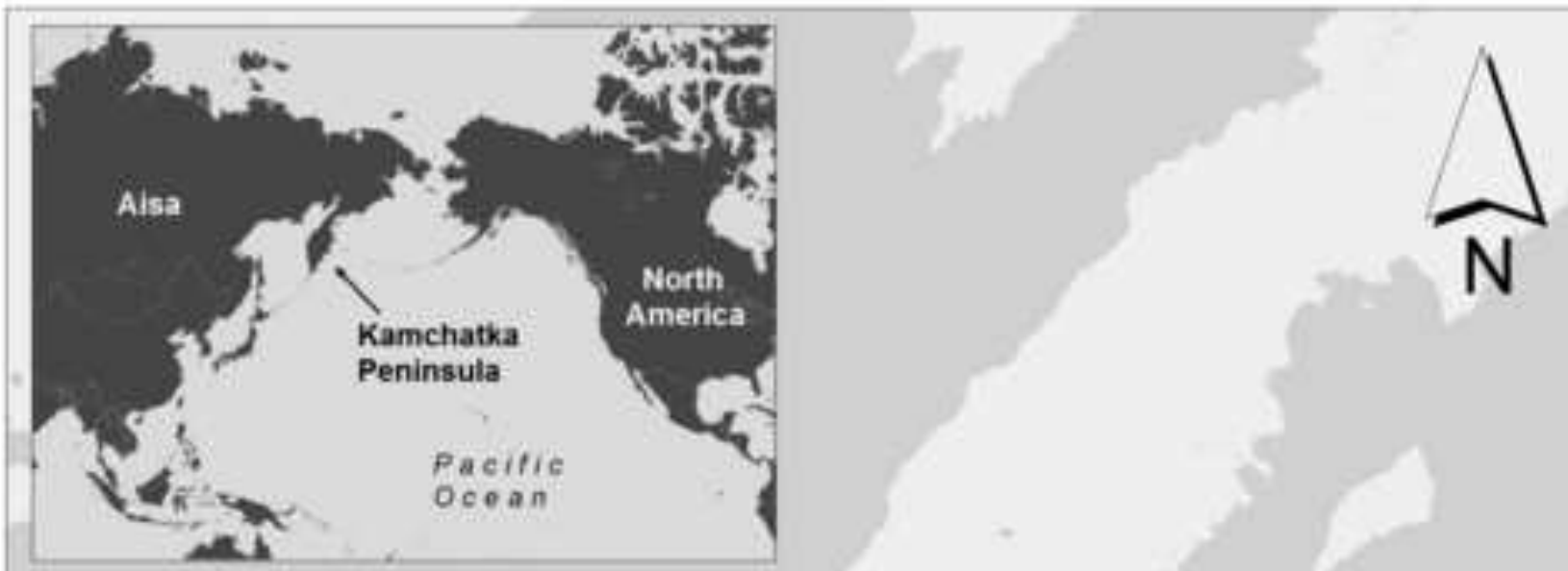

Sea of Okhotsk

Legend

A Active volcano

- Major volcano

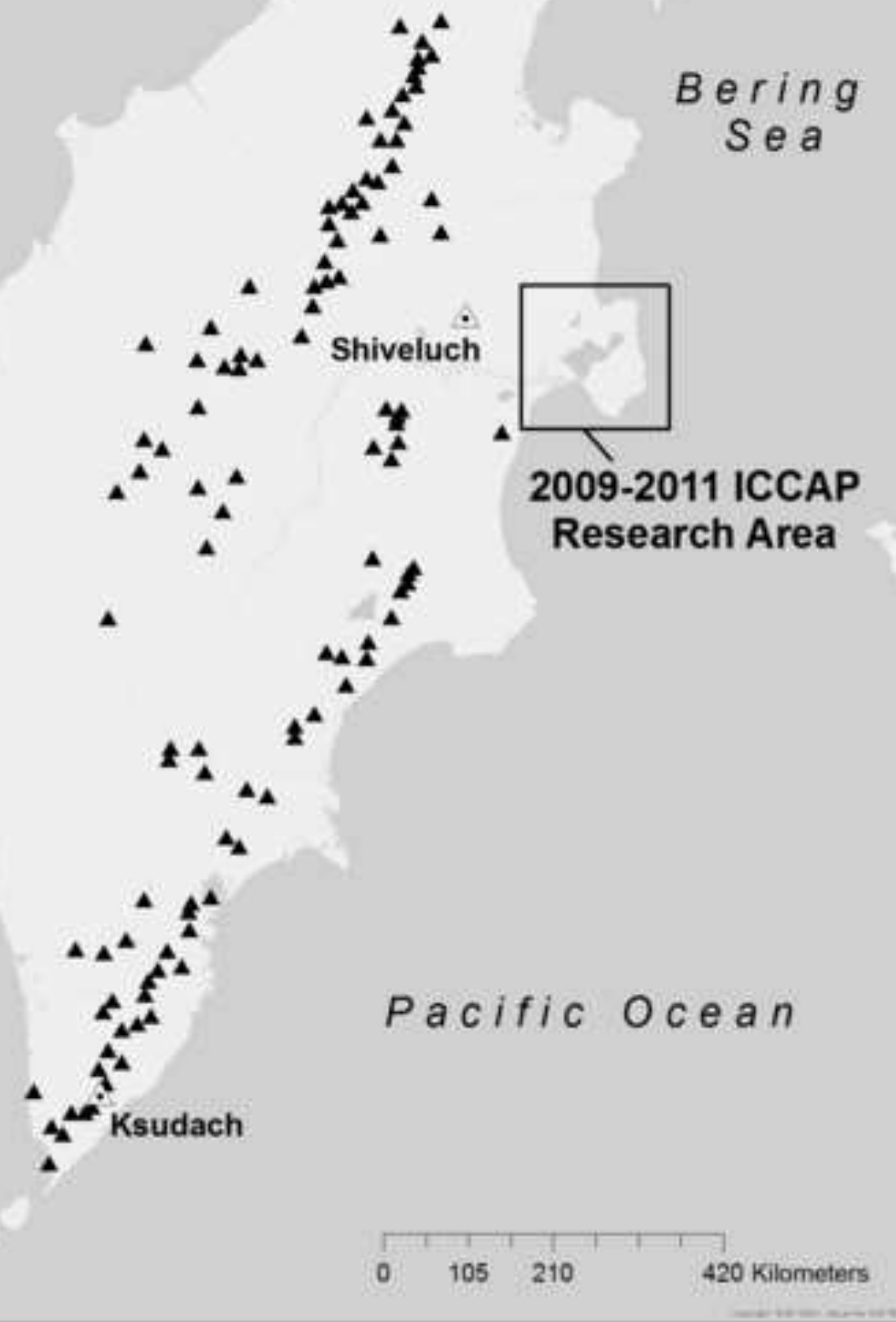




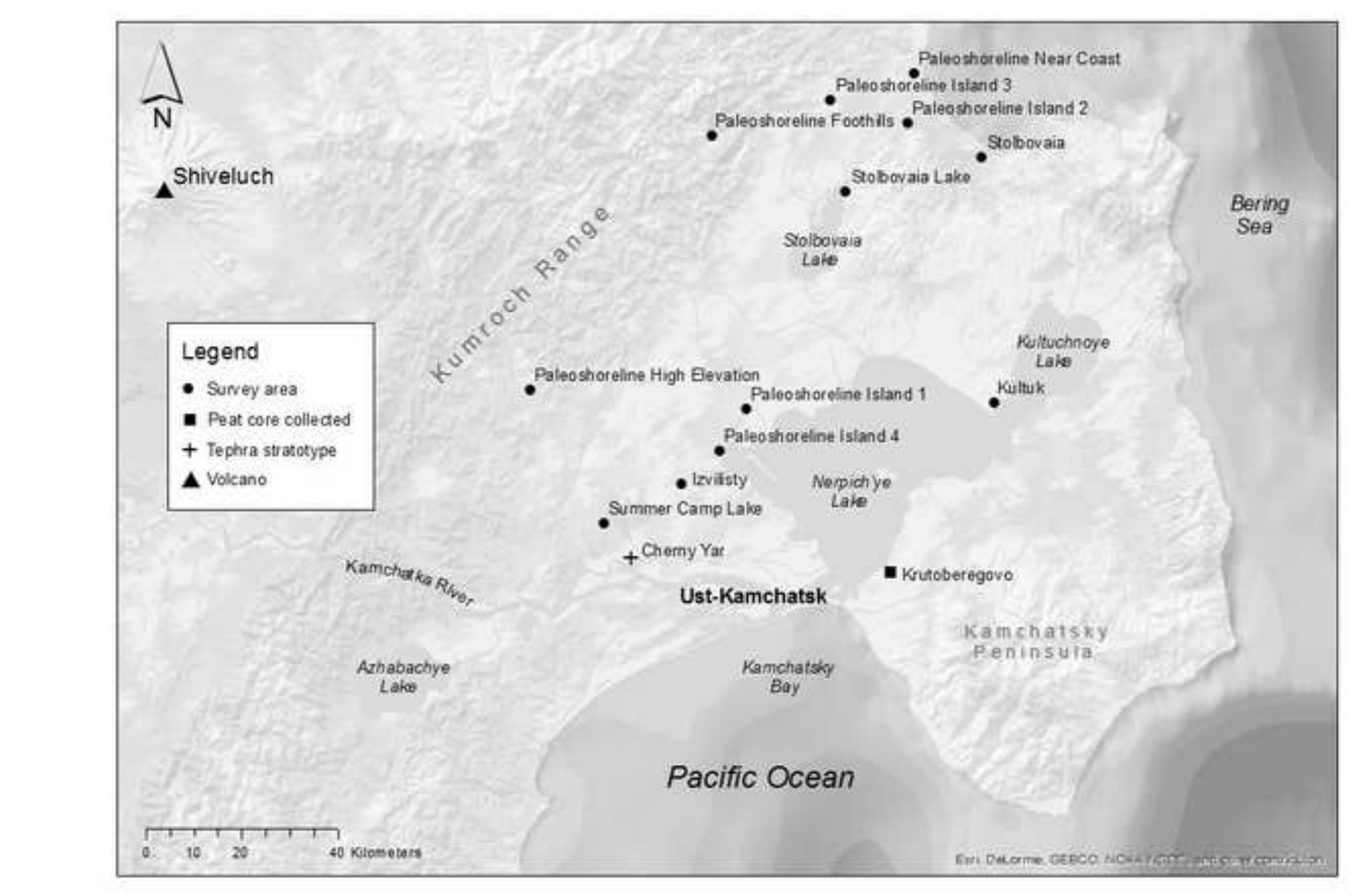




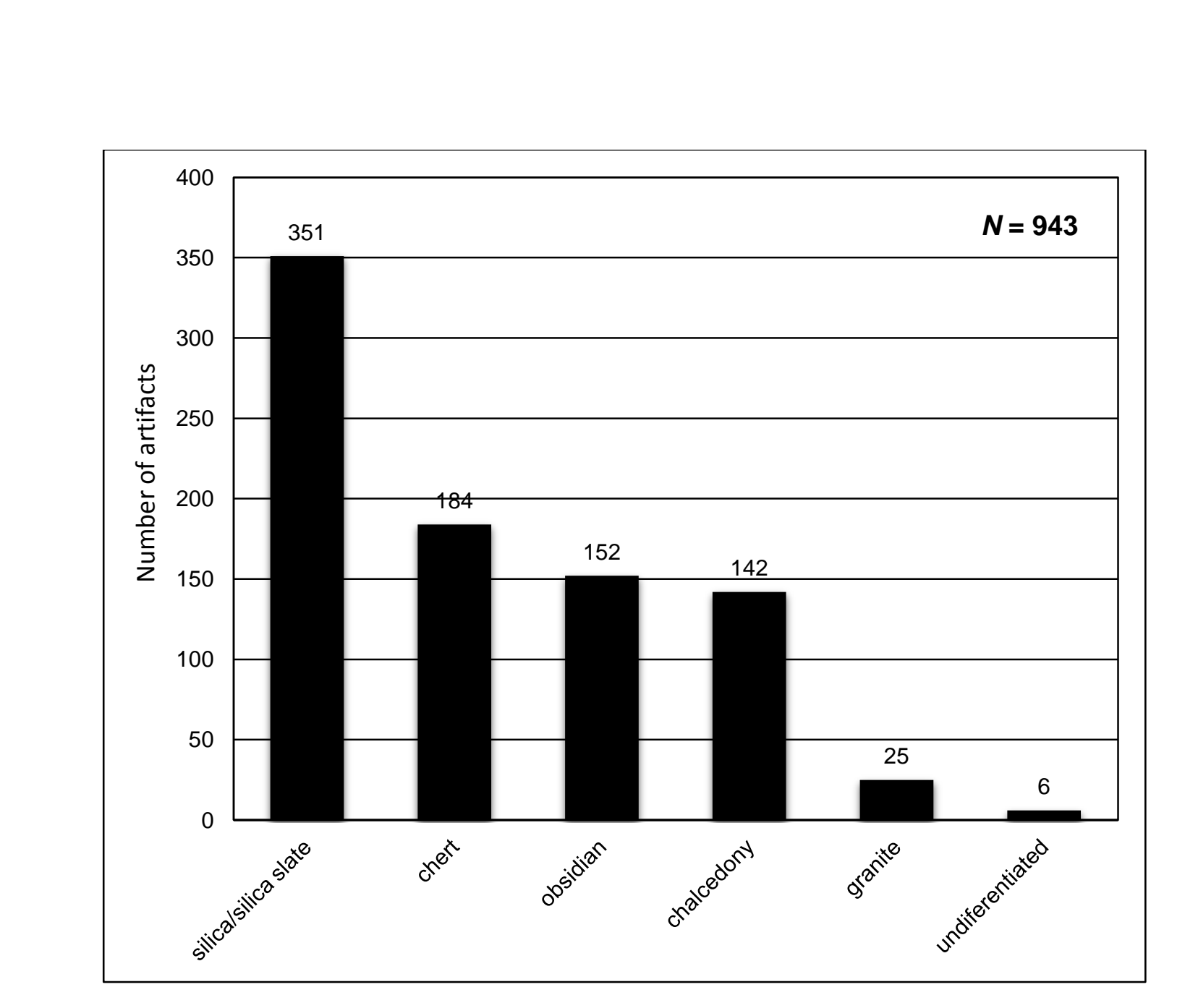

Figure 4
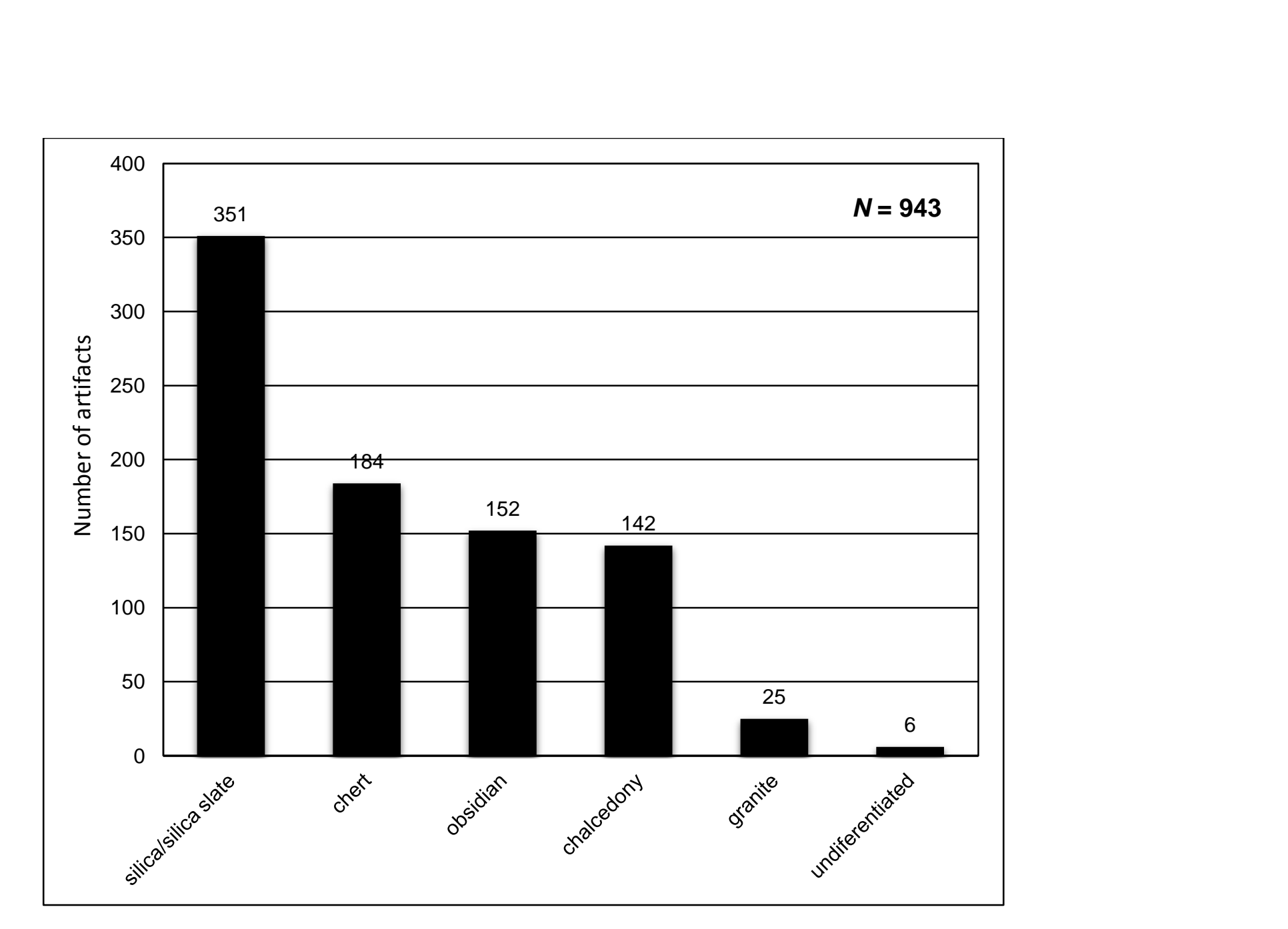

4

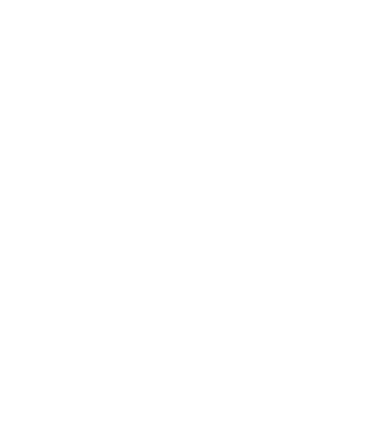
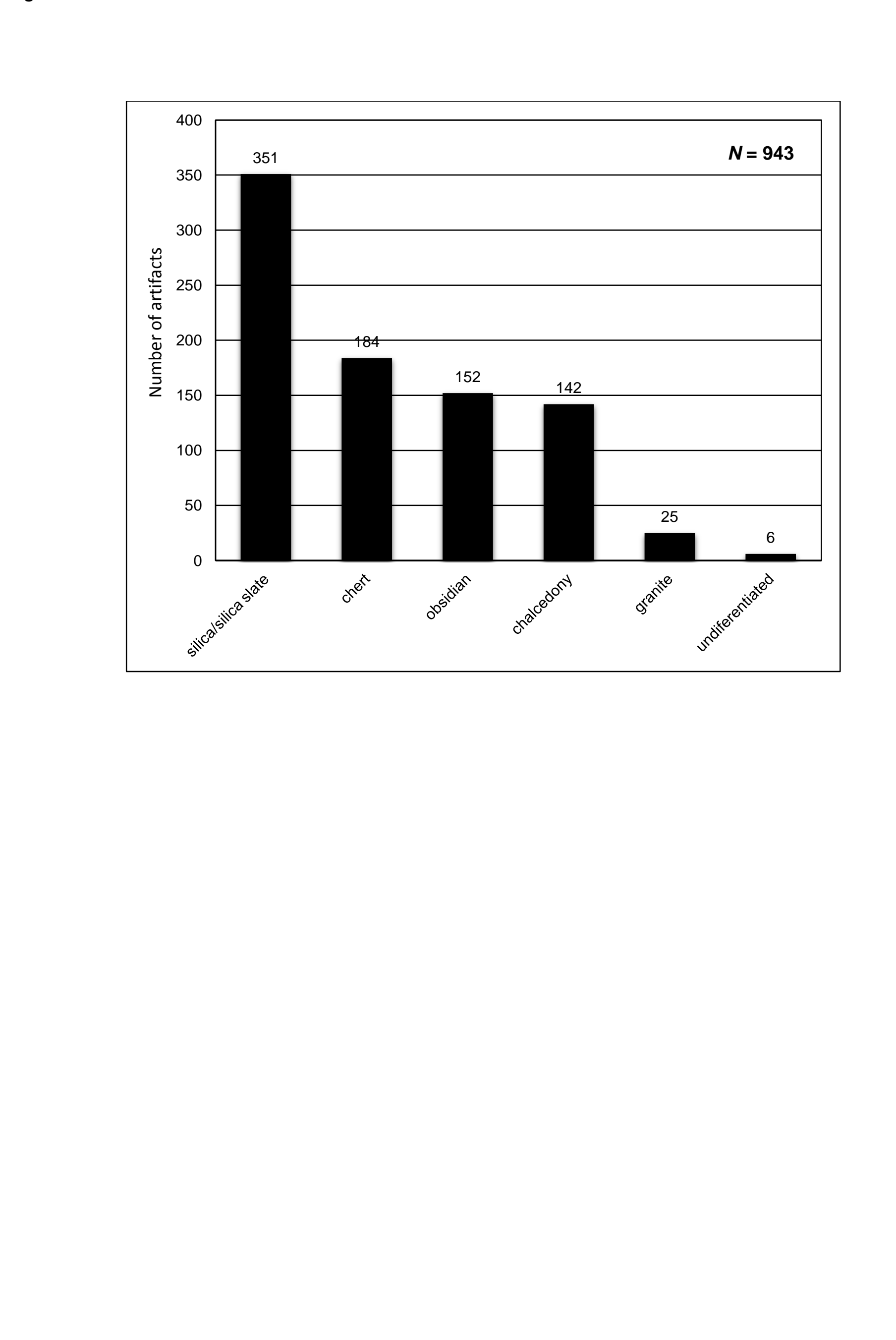

.

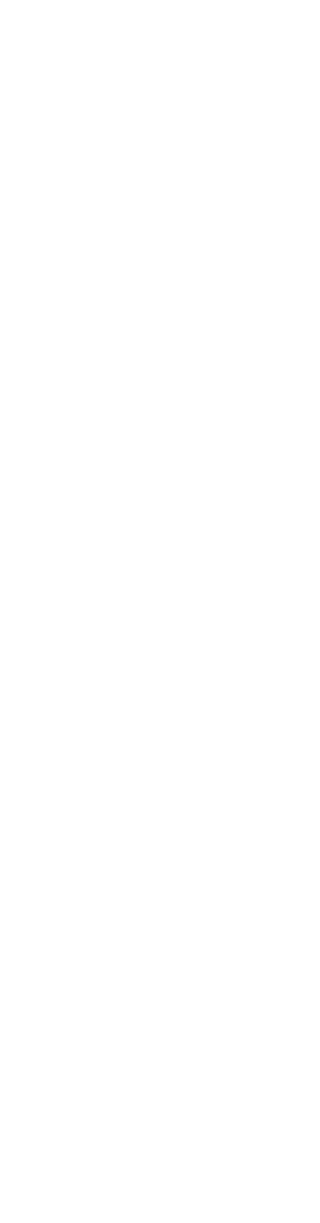


Figure 5

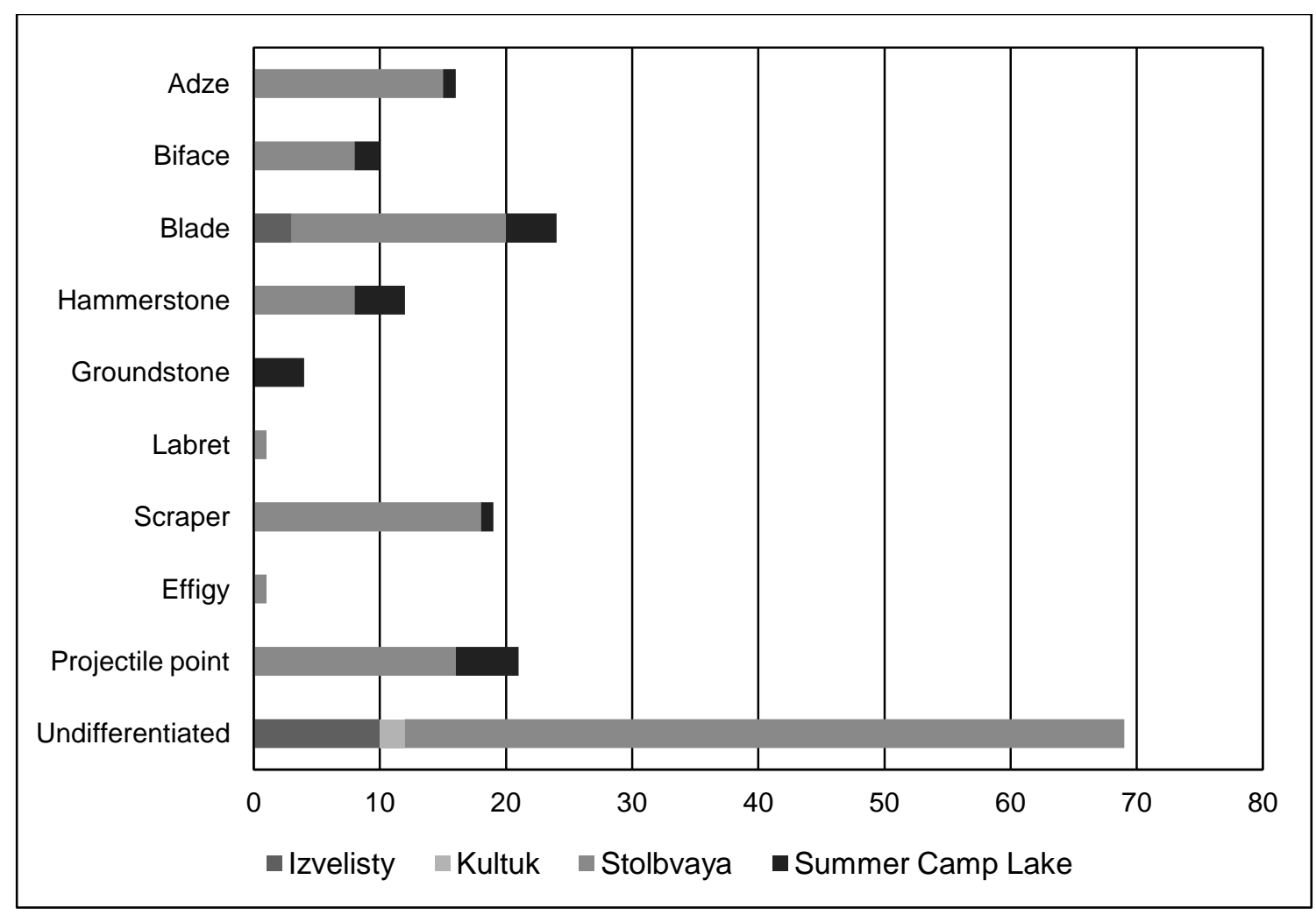


Krutoberegovo, Kamchatka Peninsula

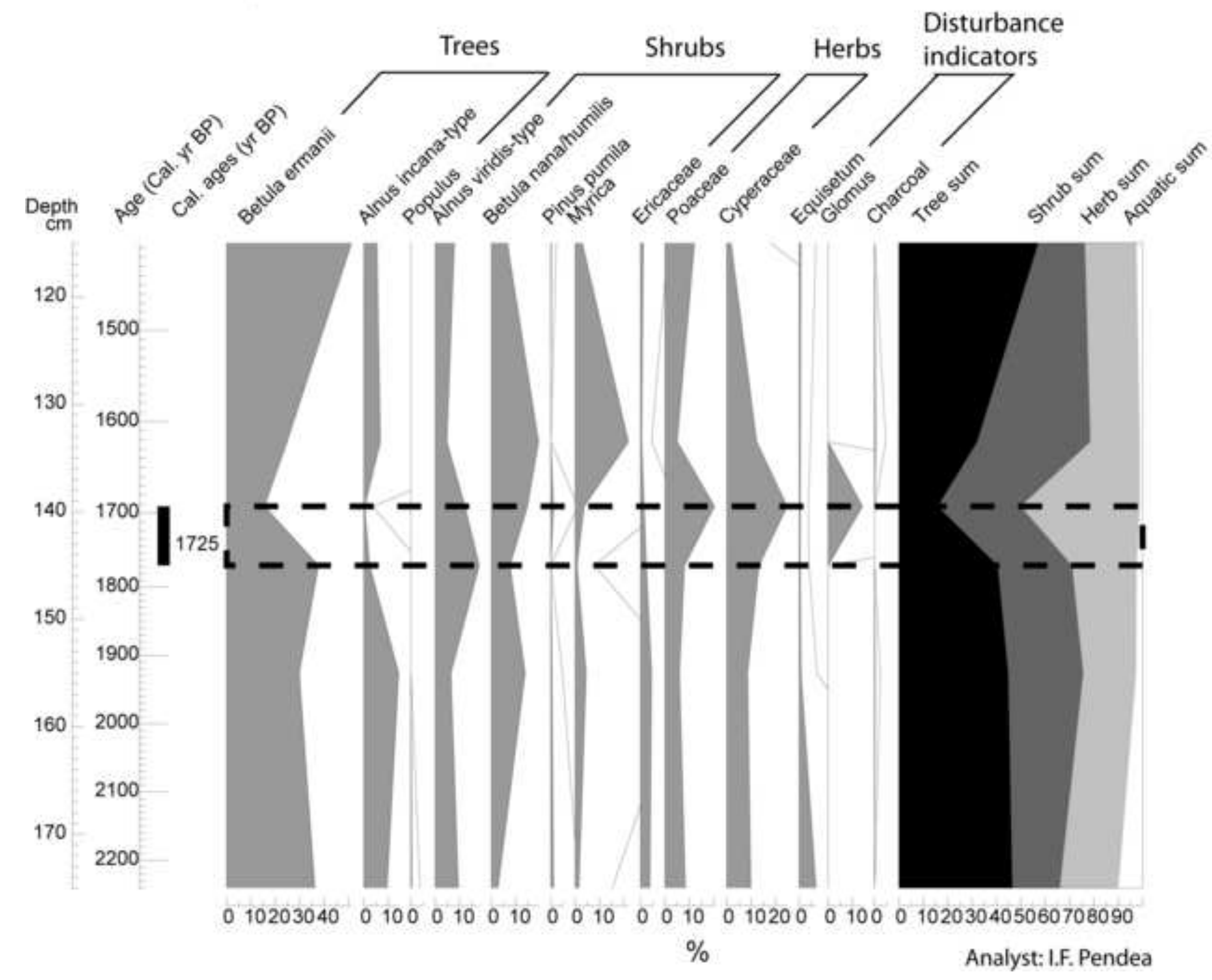


Krutoberegovo, Kamchatka Peninsula

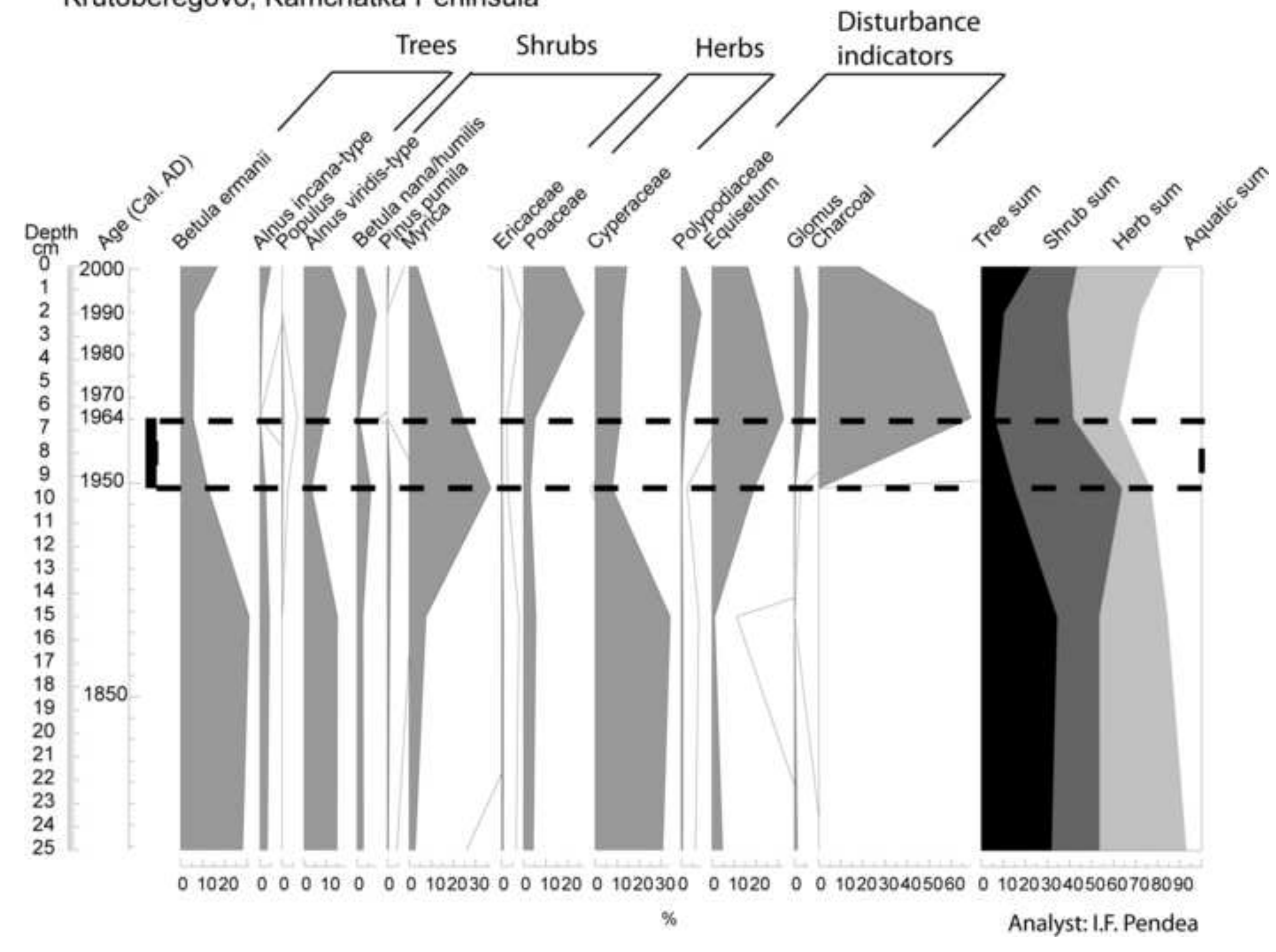




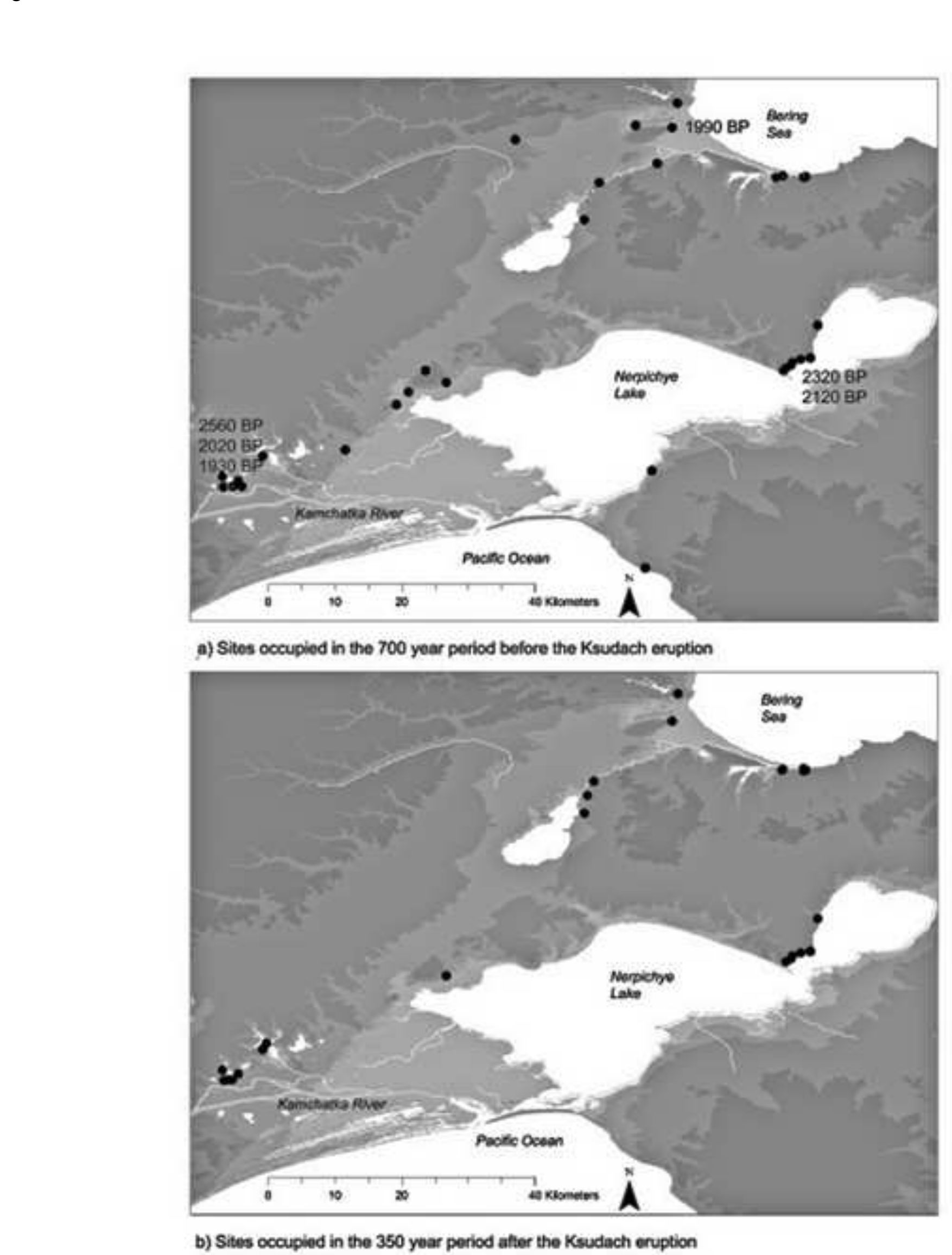

a) Sites occupied in the 700 yoar period belore the Ksudach eruption

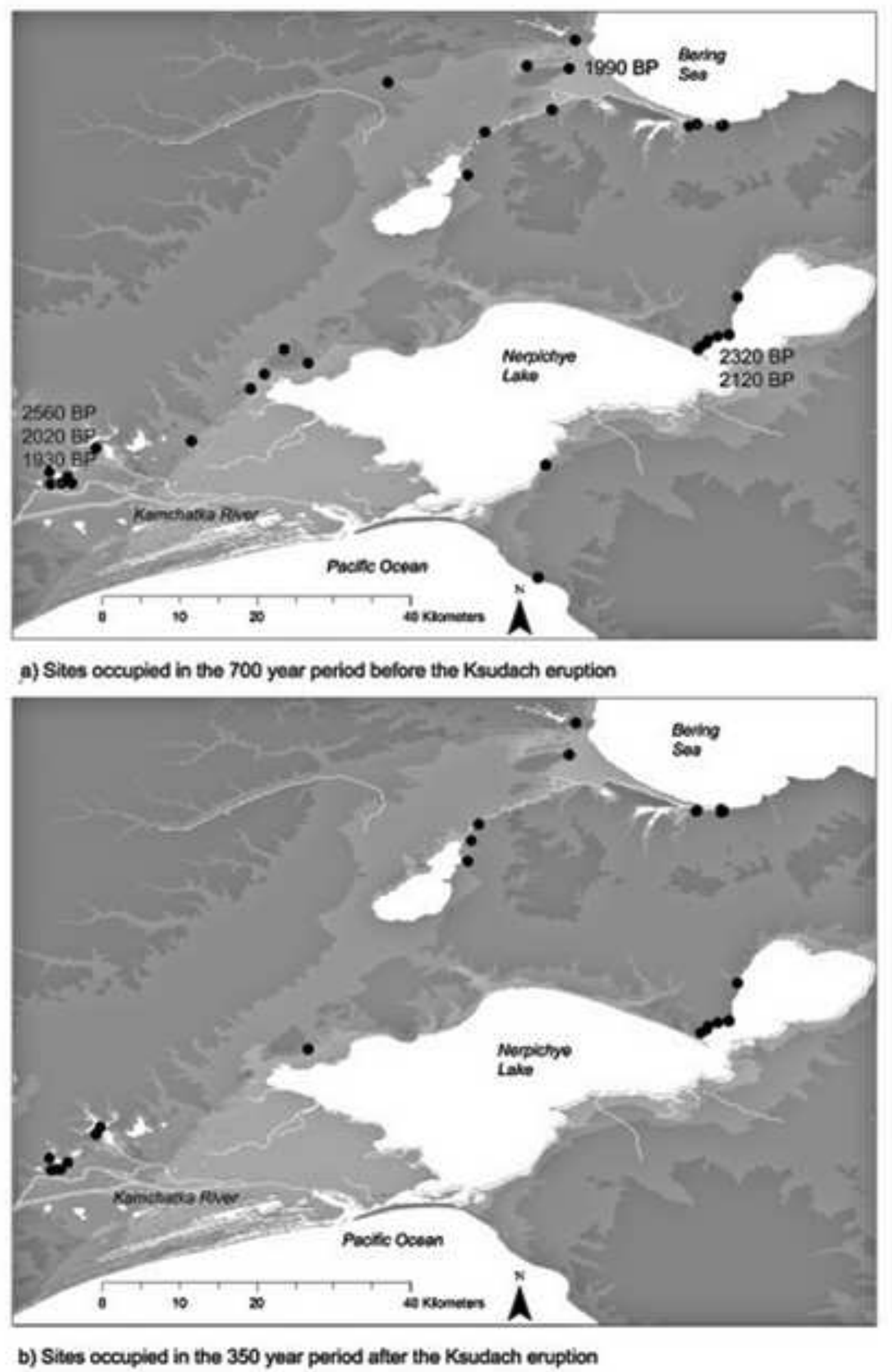

b) Sites occupled in the 350 yoar period after the Ksudach eruption

\section{.}

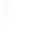

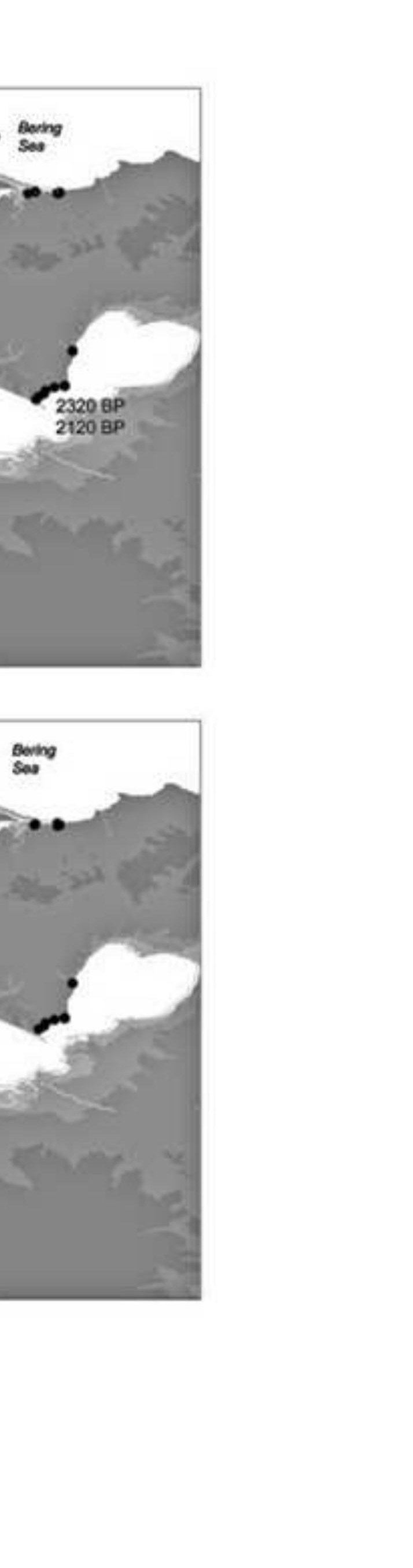




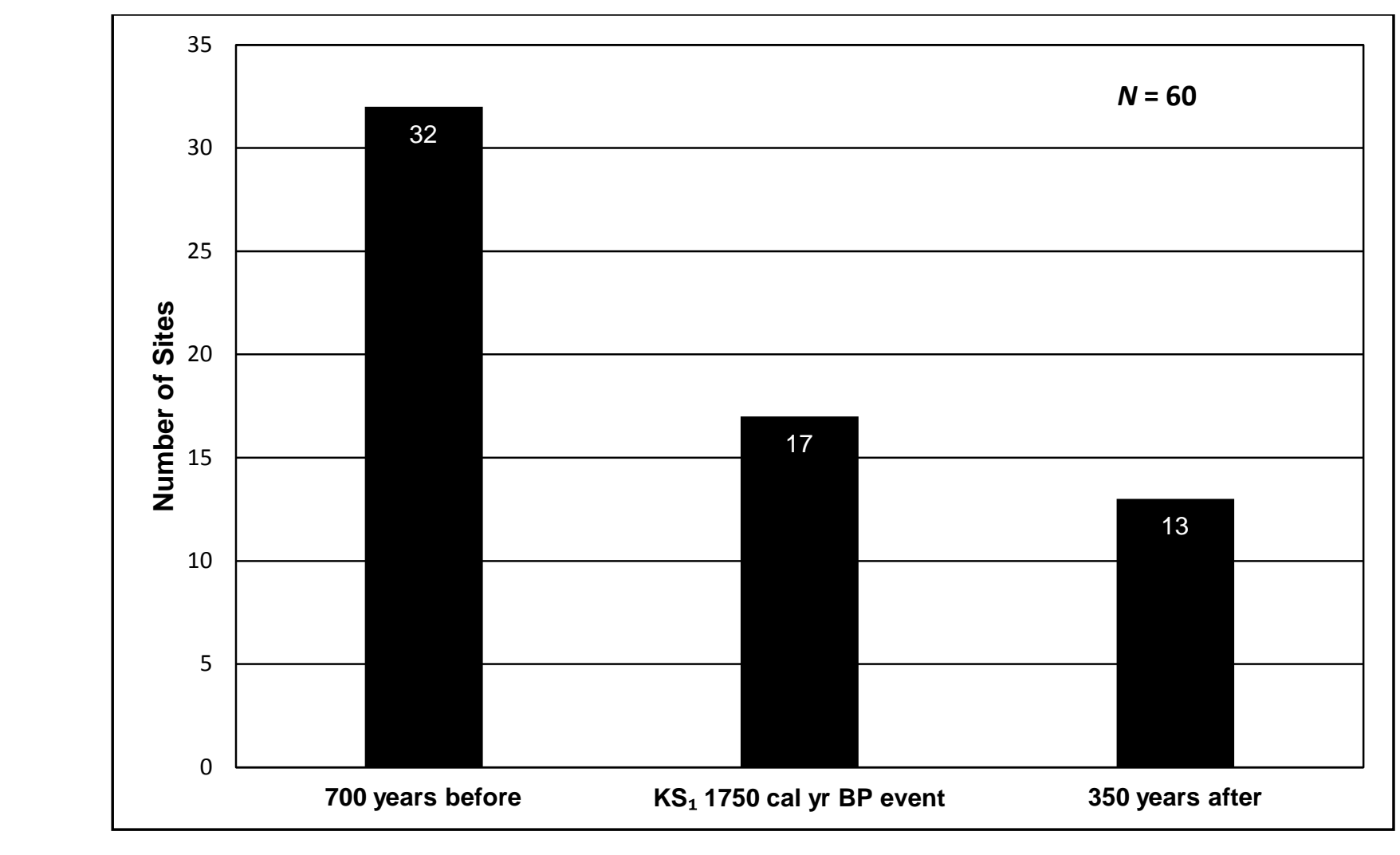

Figure 9

\section{Figure 9}

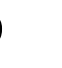

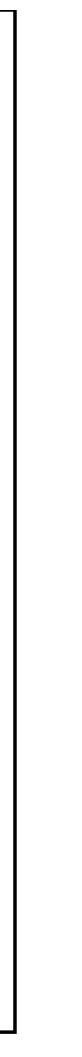

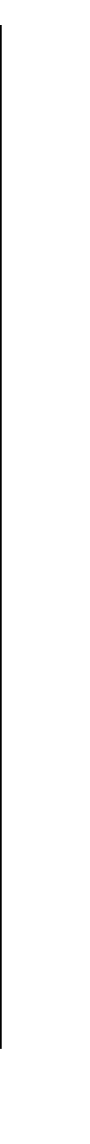

\begin{tabular}{|l|l|}
\hline 50 \\
700 years before & $\mathrm{KS}_{1} 1750$ cal yr BP event \\
\hline 0 & 350 years after \\
\hline
\end{tabular}
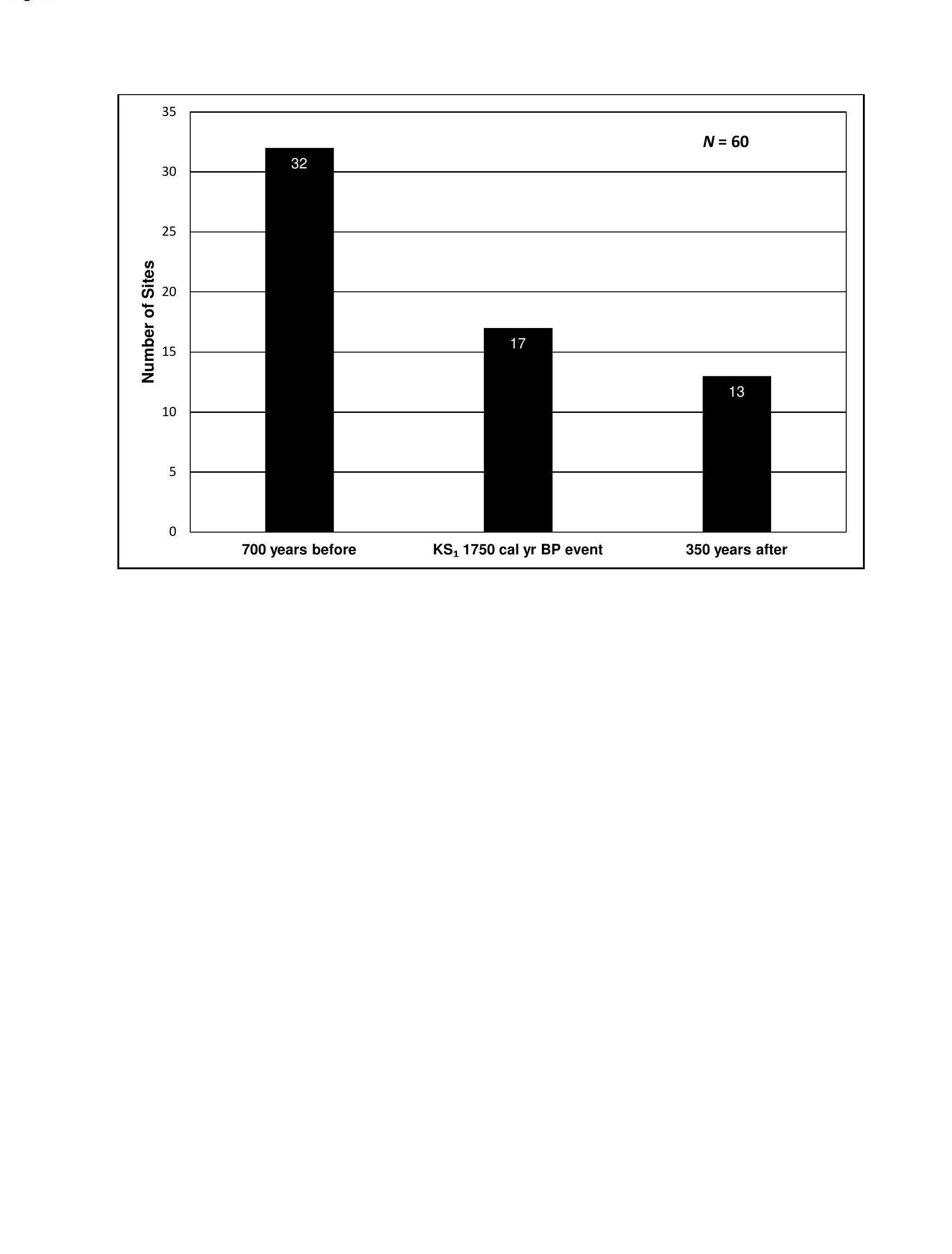


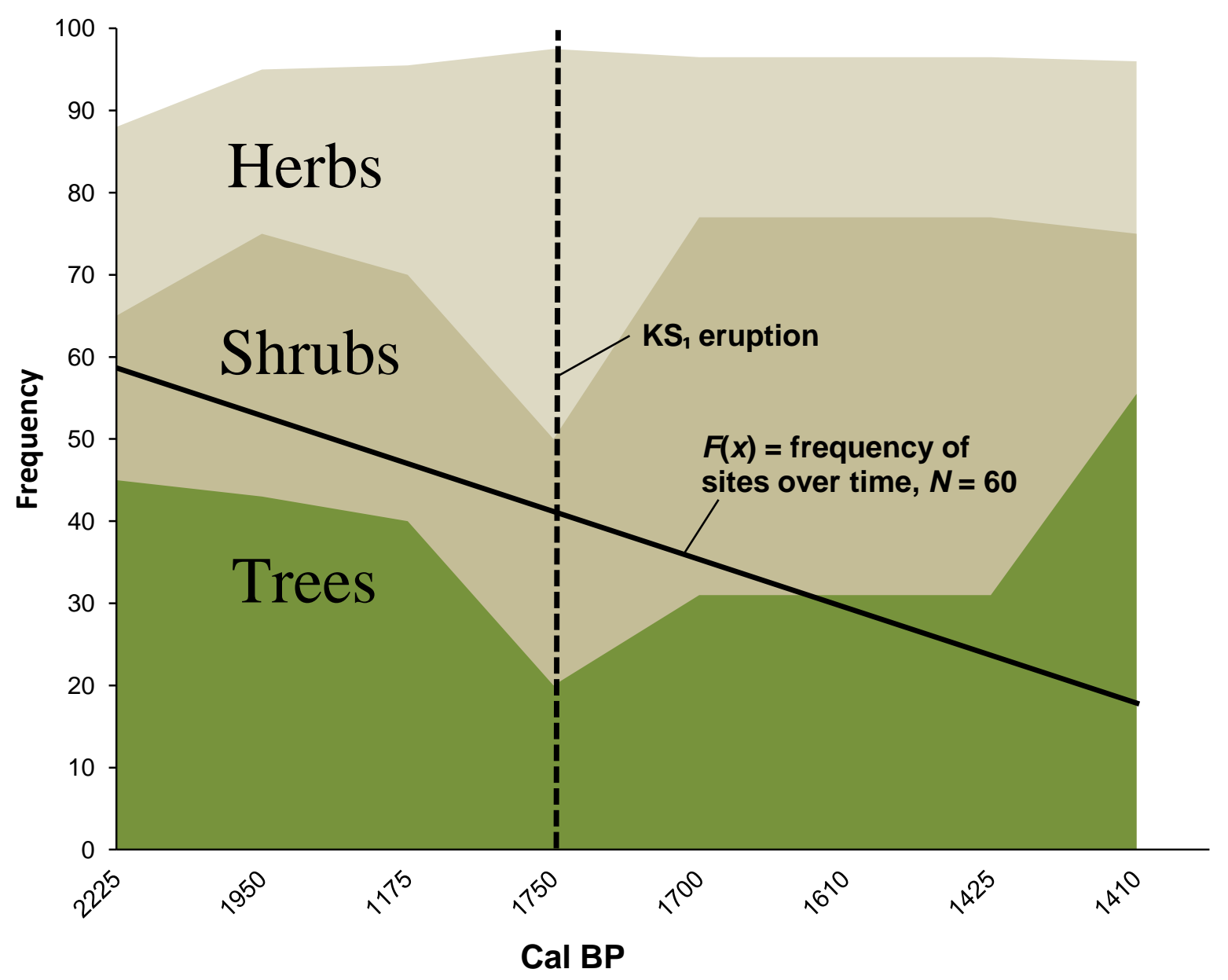


Table 1. Radiocarbon dates for sites sampled 2009 and 2010, Kamchatka Peninsula, Russia

\begin{tabular}{|c|c|c|c|c|c|c|c|}
\hline \multirow{2}{*}{ Site } & \multirow{2}{*}{ Year } & \multirow{2}{*}{$\begin{array}{l}\text { Depth } \\
(\mathrm{cm})\end{array}$} & \multirow{2}{*}{ Sample type } & \multirow{2}{*}{ Woodshole ID } & \multirow{2}{*}{$\begin{array}{l}\text { Radiocarbon } \\
\text { Age (yrs BP) }\end{array}$} & \multicolumn{2}{|c|}{$2 \sigma$ probability CAL age (yr BP) } \\
\hline & & & & & & $1^{\text {st }}$ & $2^{\text {nd }}$ \\
\hline Kultuk & 2009 & 55 & charcoal & 79021 & $2120 \pm 25$ & $2002-2152$ & $2279-2283$ \\
\hline Kultuk & 2009 & 55 & charcoal & 79022 & $2320 \pm 25$ & 2313-2358 & $\mathrm{n} / \mathrm{a}$ \\
\hline Kultuk & 2009 & 35 & charcoal & 79023 & $4120 \pm 30$ & $4528-4714$ & $4753-4815$ \\
\hline Kultuk & 2009 & 25 & charcoal & 79024 & $4120 \pm 30$ & $4528-4714$ & $4753-4815$ \\
\hline Kultuk & 2009 & 45 & charcoal & 79025 & $4180 \pm 35$ & $4610-4768$ & $4782-4837$ \\
\hline Izvilisty & 2009 & 18 & stem epidermis & 79247 & $2000 \pm 40$ & 1867-2060 & $\mathrm{n} / \mathrm{a}$ \\
\hline Izvilisty & 2009 & 24 & $\begin{array}{c}\text { Briales stem; Carex } \\
\text { leaf }\end{array}$ & 79248 & $2990 \pm 30$ & 3068-3248 & 3306-3322 \\
\hline Izvilisty & 2009 & 26 & seed fragments & 79249 & $3320 \pm 40$ & $3453-3640$ & $\mathrm{n} / \mathrm{a}$ \\
\hline Izvilisty & 2009 & 28 & leaf epidermis & 79250 & $3640 \pm 40$ & 3856-4024 & $4025-4084$ \\
\hline Summer Camp Lake & 2010 & 80 & charcoal & 85972 & $1990 \pm 25$ & 1888-1992 & $\mathrm{n} / \mathrm{a}$ \\
\hline Stolbovaia & 2010 & 90 & charcoal & 85973 & $5260 \pm 65$ & 5911-6204 & $\mathrm{n} / \mathrm{a}$ \\
\hline Kultuk & 2010 & 85 & charcoal & 85974 & $5350 \pm 35$ & 6090-6215 & 6002-6086 \\
\hline Kultuk & 2010 & 80 & charcoal & 85975 & $1080 \pm 25$ & 933-1010 & 1022-1055 \\
\hline Summer Camp Lake & 2010 & 100 & charcoal & 85976 & $1930 \pm 35$ & 1813-1953 & 1957-1987 \\
\hline Kultuk & 2010 & 123 & charcoal & 85977 & $2560 \pm 25$ & 2698-2752 & 2538-2587 \\
\hline
\end{tabular}


Table 2. Major Holocene marker tephra identified in archaeological excavations and test pits in the project area

\begin{tabular}{|c|c|c|c|c|c|}
\hline Tephra code & Source volcano & Age (cal BP) & Color & Grain size & Thickness (cm) \\
\hline $\mathrm{SH}_{1964}$ & Shiveluch & AD 1964 & Salt-and-pepper (black and white grains) & Medium to coarse & $0.5-2$ \\
\hline $\mathrm{SH}_{1450}$ & "-" & 1350 & $\begin{array}{l}\text { Salt-and-pepper (black and yellow or beige } \\
\text { grains) }\end{array}$ & Fine to medium sand & $1-3$ \\
\hline $\mathbf{K S}_{\mathbf{1}}$ & Ksudach & 1750 & Pale yellow or beige with light-gray top & $\begin{array}{l}\text { Very fine to fine } \\
\text { sand }\end{array}$ & $3-7$ \\
\hline SH2800 & Shiveluch & 3000 & Bright-yellow & Fine sand & $1-3$ \\
\hline SH3800 & Shiveluch & 4400 & Salt-and-pepper (black and white grains) & $\begin{array}{l}\text { Medium to coarse } \\
\text { sand with pumice } \\
\text { lapilli }\end{array}$ & $1-1.5$ \\
\hline SHdv & "-" & 4700 & Bright-yellow with light-gray bottom & $\begin{array}{l}\text { Fine sand to } \\
\text { medium sand at the } \\
\text { bottom }\end{array}$ & $2-5$ \\
\hline SH4800 & "-" & 5600 & Black and orange-brown grains & Fine to medium sand & 5 \\
\hline PL2 & Plosky & 10,200 & Dark brown & Coarse sand & $1-7$ \\
\hline PL1 & "-" & 11,600 & Dark brown & Fine sand & 0.5 \\
\hline
\end{tabular}


Table 3. Total numbers of sites identified between 2009 and 2011

\begin{tabular}{llc} 
Year & Survey location & Total sites \\
\hline 2009 & Izvilisty & 1 \\
2009 & Kultuk & 5 \\
\hline 2010 & Summer Camp Lake & 8 \\
2010 & Paleoshoreline Island 1 & 4 \\
2010 & Paleoshoreline Island 2 & 1 \\
2010 & Paleoshoreline Island 3 & 1 \\
2010 & Paleoshoreline Foothills & 1 \\
2010 & Paleoshoreline High Elevation & 0 \\
2010 & Paleoshoreline Near Coast & 4 \\
\hline 2010 & Stolbovaia & 15 \\
2011 & Summer Camp Lake & 6 \\
2011 & Kultuk & 6 \\
2011 & Stolbovaia Lake & 7 \\
2011 & Paleoshoreline Island 4 & 1 \\
\hline & & Total
\end{tabular}


Table 4. Variability in lithic types of artifacts recovered from four survey areas

\begin{tabular}{|c|c|c|c|c|c|}
\hline Lithic type & Izvelisty & Kultuk & Stolbavaia & $\begin{array}{c}\text { Summer } \\
\text { Camp Lake }\end{array}$ & Total \\
\hline Chalcedony & 19 & 8 & 142 & 37 & 206 \\
\hline Chert & 64 & 7 & 184 & 78 & 333 \\
\hline Granite & 0 & 0 & 25 & 0 & 25 \\
\hline Obsidian & 82 & 3 & 152 & 59 & 296 \\
\hline Silicified Igneous/Sedimentary & 0 & 5 & 351 & 12 & 368 \\
\hline Undifferentiated & 22 & 5 & 5 & 9 & 41 \\
\hline Total & 187 & 28 & 859 & 195 & 1269 \\
\hline
\end{tabular}

